\title{
Contourites along the Iberian continental margins: conceptual and economic implications
}

\author{
Estefanía Llave $^{1^{*}}$, F. Javier Hernández-Molina ${ }^{2}$, Marga García ${ }^{3}$, Gemma Ercilla $^{4}$, Cristina \\ Roque $^{5}$, Carmen Juan ${ }^{4,6}$, Anxo Mena ${ }^{2,5,7}$, Benedict Preu ${ }^{8}$, David Van Rooij ${ }^{6}$, Michele \\ Rebesco $^{9}$, Rachel Brackenridge ${ }^{10}$, Gloria Jané ${ }^{1}$, María Gómez-Ballesteros ${ }^{11}$, Dorrik Stow ${ }^{10}$ \\ 1 Instituto Geológico y Minero de España (IGME), Rios Rosas 23, 28003 Madrid, Spain. \\ 2 Dept. Earth Sciences, Royal Holloway Univ. London (RHUL), Egham, TW20 0EX, UK. \\ 3 Instituto Andaluz de Ciencias de la Tierra (IACT-CSIC), Univ. Granada, Avda. de las Palmeras, 4 , \\ 18100 Armilla (Granada), Spain. \\ 4 Centro de Investigaciones Marinas y Ambientales (CMIMA-CSIC), Paseo Marítimo Barceloneta, \\ 37-49, 08003 Barcelona, Spain. \\ 5 Divisão de Geologia e Georecursos Marinhos, IPMA, Lisboa, Portugal. \\ 6 Dept. Geology \& Soil Science, Ghent Univ., Krijgslaan 281 S8. B-9000 Gent, Belgium. \\ 7 Dpto. de Xeociencias Mariñas e O.T., Univ. Vigo, E-36310 Vigo (Pontevedra), Spain. \\ 8 Chevron Corporation, 6001 Bollinger Canyon Road, San Ramon, California 94583, United States. \\ 9 OGS, Istituto Nazionale di Oceanografia e di Geofisica Sperimentale, Borgo Grotta Gigante 42 /C, \\ 34010 Sgonico, TS, Italy. \\ 10 IPE, Heriot-Watt Univ. Edinburgh EH14 4AS, Scotland, UK. \\ 11 Instituto Español de Oceanografía (IEO), C/Corazón de María 8, 28002 Madrid, Spain. \\ *Corresponding author email: e.llave@igme.es
}

Abstract:

This work uses seismic records to document and classify contourite features around the Iberian continental margin to determine their implications for depositional systems and petroleum exploration. Contourites include depositional features (separated, sheeted, plastered and confined drifts), erosional features (abraded surfaces, channels, furrows and moats) and mixed features (contourite terraces). Drifts generally show high to moderate amplitude reflectors, which are cyclically intercalated with transparent layers. Transparent layers may represent finer grained deposits, which can serve as seal rocks. High amplitude reflectors (HARs) likely represent sandier layers, which could form hydrocarbon reservoirs. HARs occur on erosive features (moats and channels) and are clearly developed on contourite terraces and overflow features. Most of the contourite features described here are influenced by Mediterranean water masses throughout their Pliocene and Quaternary history. They specifically record Mediterranean Outflow Water following its exit through the Gibraltar Strait. This work gives a detailed report on the variation of modern contourite deposits, which can help inform ancient contourite reservoir interpretation. Further research correlating $2 D$ and $3 D$ seismic anomalies with core and well logging data is needed to develop better diagnostic criteria for contourites. This can help clarify the role of contourites in petroleum systems. 
Key words: sandy contourites, high amplitude reflectors (HARs), water massseafloor interaction, hydrocarbon exploration, Iberian continental margin

\section{INTRODUCTION}

The characterization of contourite features has been a critical area of research in marine geology over the past three decades due to their implications for stratigraphy, sedimentology, paleoceanography, paleoclimatology, sedimentary instability processes, and energy resources (Rebesco et al., 2014). Studies have shown that contourites are common in deep marine environments, but remain poorly understood in terms of their composition, sedimentary processes, origin, sequence, lithology, seismic facies, petrophysical characteristics (porosity, permeability, etc.) and role in petroleum systems (Viana, 2008; Stow et al., 2011a, b; Shanmugan, 2012; Brackenridge, 2014; among others). Advances in understanding of contourites have yielded a clearer picture of their lateral and temporal variability as well as their relations with along-slope processes. Previous work has helped formalize the terms Contourite Depositional System (CDS) and Contourite Depositional Complex (CDC) (Hernández-Molina et al., 2003, 2008; Rebesco and Camerlenghi, 2008). Contourites however frequently occur interbedded or simultaneously deposited with sedimentary facies resulting from down-slope processes. These deposits represent mixed turbidite-contourite systems (Faugères et al., 1999; Rebesco and Camerlenghi, 2008; Creaser et al., 2017). Mixed systems are common along continental margins where bottom currents rework and/or redistribute pre-existing gravitational deposits (Marchès et al., 2010; Mulder et al., 2013; Brackenridge et al., 2013). When down-slope processes dominate along-slope processes, gravitational deposits (such as turbidites) may overprint or inhibit the development of contourites. When strong along-slope currents dominate, turbidity currents may deviate and feed contourite drifts (e.g., Faugères et al., 1999; Mulder et al., 2003, 2006; Viana et al., 2007).

This paper follows the contourite drift classification criteria of Faugères et al. (1999) and Rebesco (2005). Sediment drifts are commonly bounded by and/or associated with erosional contourite features (such as contourite channels or moats). Compared to depositional features, these latter erosional features have generally received less attention and their 
Downloaded from http://sp.lyellcollection.org/ at Consejo Superior De Investigaciones Cientificas (CSIC) on March 6, 2020

genetic relationships with oceanographic processes remain unclear (Nelson et al., 1993, 1999; Stow and Mayall, 2000; Hernández-Molina et al., 2006, 2008a, 2015a, 2015b; García et al., 2009). Erosional contourite features are clearly identifiable in seismic reflection profiles allowing large-scale interpretation (Faugères et al., 1999; Stow et al., 2002; HernándezMolina et al., 2008, 2015c; Nielsen et al., 2008; Brackenridge et al., 2013; Llave et al., 2015; Kuijpers and Nielsen, 2016; Calvin Campbell and Mosher, 2016; Delivet et al., 2016; Gruetzner and Uenzelmann-Neben, 2016, among others). In the past, some contourite deposits have been considered as potential (hydrocarbon) source rocks, but ones less likely to form reservoirs than turbidites (Pickering et al., 1989; Pickering and Hiscot, 2016). Sediments that make up such contourite drifts are typically muddy but can reach substantial local thickness and include well-sorted sands, that themselves are thick and laterally extensive enough play a role in deep-water petroleum systems. Recent studies have interpreted bottom currents as a crucial factor in hydrocarbon reservoir development because weak flows enable accumulation of mud-rich deposits (such as contourites). These can serve as both caprock (seals) or with deeper burial, as potential source rocks or shalegas reservoirs when adequately enriched in organic matter (up to $2 \mathrm{wt}$ \%). On the other hand, high velocity flows may represent a mechanism for "mature sand" accumulation in deep-water environments. These sands form excellent reservoir units (Enjorlas et al., 1986; Colella, 1990; Mutti, 1992; Shanmugam et al., 1993; Viana et al., 1998; Stow and Faugères, 2008; Viana, 2008; Stow et al., 2011b, 2013a; Shanmugam, 2006, 2012, 2013a, b; Mutti and Carminatti, 2012). Sandy contourites and related deposits with good lateral continuity and exposed to long-term effects of current winnowing may have greater textural maturity and better developed primary interstices than turbidites. Sandy contourites can thus present good petrophysical characteristics, including high values for porosity, permeability, and lateral and vertical transmissivity of fluids (Shanmugam, 2008; Viana, 2008).

In spite of the potential role they play in deep-water petroleum systems and by extension, their economic significance, contourites and mixed-drift depositional systems are not well understood. In particular, the scientific literature on sandy contourites, including ancient analogues in outcrop is sparse. Mixed-drift systems do not yet enjoy the benefit of well-defined interpretive models. Both of these could help refine and direct turbidite exploration.

Published seismic and sedimentologic data from the Iberian continental margin have reported on the interrelations of turbidite and contourite depositional systems, especially contourites within mixed turbidite-contourite systems (Mulder et al., 2003, 2006, 2008; Llave et al., 2006; Marchès et al., 2007; Hernández-Molina et al., 2010; 
García et al., 2016). The Iberian margin is affected by several vigorous water masses interacting along upper and middle continental slopes and by weaker water masses moving along the lower slope and abyssal plains (Hernández-Molina et al., 2011, 2016a) (Fig. 1). Each of these domains hosts extensive and complex contourite features of variable dimensions and sedimentary thicknesses that are often poorly understood in terms of their oceanographic / depositional contexts (Maestro et al., 2013; Llave et al., 2015). Along the Iberian margin, large volumes of sand have been efficiently transported, re-deposited or reworked by the persistent hydrodynamic regimes of the Gulf of Cadiz (Buitrago et al., 2001; Habgood et al., 2003; Llave et al., 2005; Hernández-Molina et al., 2006; Akhmetzhanov et al., 2007; Brackenridge et al., 2011, 2013). IODP Expedition 339 and and other cores from a number of cruises furthered understanding of sand-rich contourite deposits by presenting a facies model for sandy contourites (Expedition 339 Scientists, 2012; Hernández-Molina et al., 2013; Stow et al., 2013b, Brackenridge et al., 2018). This research also considered contourites' potential role in deep-water petroleum systems. A thorough record of these features as they occur around the Iberian margin can further understanding of both their scientific significance and their economic potential (e.g., Rebesco and Camerlenghi, 2008; Hernández-Molina et al., 2011 and references therein).

This study provides a regional review of along-slope processes and their sedimentary features around the lberian continental margin based on 2D seismic profiles from published and unpublished sources. This work also discusses sandy contourites and how these features can be used to interpret ancient contourite deposits and explore for petroleum in deep-water settings.

\section{DATA AND METHODOLOGY}

This study interprets geophysical surveys of the Iberian continental margin. Surveys used acoustic techniques to develop a $2 \mathrm{D}$ vertical profile of the structure underlying the seafloor at water depths of 200 to $5000 \mathrm{~m}$. This study primarily reviews contourite features as characterized by methods and nomenclature described in Faugères et al. (1999) and further developed by Rebesco and Stow (2001) and Nielsen et al. (2008). Contourite morphologies developed at different depths and under the influence of multiple water masses are defined as Contourite Features (CFs). Thickness is expressed in two way travel time seconds (s). 
Downloaded from http://sp.lyellcollection.org/ at Consejo Superior De Investigaciones Cientificas (CSIC) on March 6, 2020

The dataset was collected by several Spanish and international research projects as well as by commercial petroleum exploration projects. Data were made available through the Geophysical Information System (Sistema de Información Geofísico - SIGEOF (http://cuarzo.igme.es/sigeco/default.htm), the Institut de Ciències del Mar-CSIC (http://www.icm.csic.es/geo/gma/SurveyMaps/) and the Instituto Portugues do Mar e da Atmosfera-IPMA (http:// www.ipma.pt). Data were obtained by various seismic reflection methods described here. Low resolution methods are commonly used for hydrocarbon exploration purposes. These methods record multi-channel seismic profiles penetrating several kilometers but provide comparatively low resolution (> $50 \mathrm{~m}$ ) images. Moderateresolution / penetration methods use air-guns (Uniboom and Sparker) that penetrate from $100 \mathrm{~m}$ to $2 \mathrm{~km}$ with a resolution of 1 and $10 \mathrm{~m}$ (respectively). High-resolution / low penetration seismic methods use $3.5 \mathrm{kHz}$ echo sounders, TOPAS (topographic parametric sonar) and Parasound, which penetrate the upper few to tens of meters of the subsurface and record it at centimeter resolution. The various penetration depths and resolutions of these seismic survey systems record contourite features on different scales. Morphology and boundaries of the deposit are recorded at larger scales. The architecture of discrete internal depositional units is recorded at medium scales, and seismic facies are recorded at smaller scales. These features are referred to as first-, second- and third-order seismic elements in Nielsen et al. (2008).

A digital bathymetric model obtained from Zitellini et al. (2009) and GEBCO (2003) served as the base map used in the study. The World Ocean Atlas 2012 provided source data for the selected vertical hydrographic profiles.

\section{CONTOURITE FEATURES ALONG THE IBERIAN MARGIN}

The water masses around Iberia control along-slope sedimentation and thus shape intermediate- and deep-water bathymetric features (Hernández-Molina et al., 2011 and references therein) (Fig. 1 and Table I). In spite of many bottom current measurements, the Iberian margin lacks of long-term hydrodynamic records and has many areas with few or no measurements. Its mean recorded velocities are commonly low (5 to $15 \mathrm{~cm} / \mathrm{s}$ ), but certain water masses can travel across the seafloor at relatively high velocities, exceeding $80 \mathrm{~cm} / \mathrm{s}$ and occasionally reaching almost $300 \mathrm{~cm} / \mathrm{s}$, for example within the Strait of Gibraltar (Mélières et al., 1970; Madelain, 1970; Ambar and Howe, 1979; lorga and Lozier, 1999; Candela, 2001). These water masses interact along the upper and middle continental slopes and with less intensity, along lower slope areas and the abyssal plain (Fig. 1).

Contourite features with large-scale dimensions and a range of sedimentary thicknesses occur at the following locations: the northeast Iberian margin, Alboran Sea, Gulf of Cadiz 
Downloaded from http://sp.lyellcollection.org/ at Consejo Superior De Investigaciones Cientificas (CSIC) on March 6, 2020

CDS (well-studied), western Iberian margin, Galician margin, Ortegal Spur, and Le Danois Bank or "Cachucho". These features are complex and poorly understood. The next section summarizes the main water masses shaping the Iberian margin and describes contourite features formed by their interaction with the seafloor.

\subsection{Mediterranean Sea}

\subsection{A. Oceanographic setting}

According to traditional definitions, the Mediterranean Sea hosts three main water masses (Fig. 1 and Table I): Atlantic Water, Levantine Intermediate Water and Western Mediterranean Deep Water.

Atlantic Water (AW) or Modified Atlantic Water (MAW) forms due to mixing of North Atlantic Surface Water, which enters through the Strait of Gibraltar at a velocity of approximately 1 m/s (Salat and Cruzado, 1981; Gascard and Richez, 1985). The MAW flows eastwards at a depth of 100-200 m and forms two anticyclonic gyres (Fig. 1), a quasi-permanent gyre in the western Alboran basin (Western Alboran Gyre; WAG) and a semi-permanent gyre in the eastern Alboran basin (Eastern Alboran Gyre; EAG) (e.g., Perkins et al., 1990; Millot, 1999; Robinson et al., 2001). The energy of the WAG may exert an effect down to water depths of approximately 500-700 m (Cheney and Doblar, 1982; Heburn and La Violette, 1990; Perkins et al., 1990; Viúdez et al., 1998).

Levantine Intermediate Water (LIW) originates in the Strait of Sicily and flows westwards into the Western Mediterranean at depths of 200-600 m. After emerging from the Strait of Sicily, the LIW flows along the Iberian margin and into the central part of the Alboran Sea at velocities of up to $14 \mathrm{~cm} / \mathrm{s}$ (Fig. 1).

Western Mediterranean Deep Water (WMDW) forms locally in the Alboran basin and its surroundings during winter months and generally flows westwards at water depths down to $600 \mathrm{~m}$, although it can also reach depths of $2000 \mathrm{~m}$ (Fig. 1). Certain WMDW pulses can travel at velocities as high as 22 cm/s (Gascard and Richez, 1985; Parrilla and Kinder, 1987; Millot, 1999; Fabres et al., 2002).

In recent studies of the Strait of Gibraltar and nearby Alboran Sea, Millot $(2009,2014)$ proposed a more complex oceanographic structure and defined two additional water masses for this area: Western Intermediate Water (WIW; 100 to $300 \mathrm{~m}$ ), situated between the AW and LIW, and Tyrrhenian Dense Water (TDW; variable water depth), situated between the LIW and WMDW (Fig. 1). Ercilla et al. (2016) categorized these five Alboran Sea water masses as light or intermediate water masses (Light Mediterranean Waters - LMW-; 100 to $600 \mathrm{~m}$ ) and dense or deep-water masses (Dense Mediterranean Waters - DMW-; >275 m). 
Downloaded from http://sp.lyellcollection.org/ at Consejo Superior De Investigaciones Cientificas (CSIC) on March 6, 2020

\subsection{B. Contourite features (CFs)}

The best-studied contourites in the Mediterranean Sea occur in the Alboran Sea. Evidence also indicates contourite deposition elsewhere along eastern margins of Iberia. Along the continental slope between Cap de Creus and Blanes Canyons (Fig. 2A, Table II), two mounded, upward-prograding stratified drifts reach thicknesses of approximately $1 \mathrm{~s}$ and widths of $5 \mathrm{~km}$ at water depths of 1000-2300 m (Barcelona CFs). One of these occurs just south of La Fonera Canyon at water depths of 1200-2300 m (Canals, 1985), and another is located between La Fonera and Blanes Canyons at depths of 1000-1300 m (Fig. 2B). This second drift has not been analysed for specific contourite features but is similar to the one studied by Canals (1985).

Upslope, prograding, mounded, elongated and separated drifts (hereafter referred to simply as separated drifts) have been described from several localities. An isolated separated drift south Blanes Canyon reaches about $0.8 \mathrm{~s}$ thickness and $6 \mathrm{~km}$ width (Fig. 3A). A broad separated drift north of Menorca occurs on the lower slope at depths down to $2000 \mathrm{~m}$. This drift is approximately $150 \mathrm{~km}$ long, $0.5 \mathrm{~s}$ thick, $25 \mathrm{~km}$ wide and reaches $100 \mathrm{~m}$ elevation above the seafloor (Menorca CFs) (Fig. 3B). This drift also exhibits sediment waves and a contourite moat (200 m deep, $5 \mathrm{~km}$ wide) along its seaward margin (Mauffret, 1979; Velasco et al., 1996; Ercilla et al., 2000). Sediment waves also occur along the Gulf of Valencia continental margin (Valencia CFs). One of these situated along the outer continental shelf exhibits wavelengths of $400-800 \mathrm{~m}$ and heights of 2-4 m. A second example at 250 to $850 \mathrm{~m}$ water depth exhibits wavelengths of 500 to $1000 \mathrm{~m}$ and wave amplitudes of 2 to $50 \mathrm{~m}$ (Ribó et al., 2016). This latter field of sediment waves is developed along a possible prograding plastered drift approximately $0.5 \mathrm{~s}$ thick (Fig. 3C, Table II). Several separated drifts have also been identified developed locally around seamounts in this sector (Fig. 3D).

Several plastered drifts with upslope-prograding stacking pattern have also been reported. These include a 10-km-wide plastered drifts with thicknesses ranging from 1 to 0.5 $\mathrm{s}$ and developed at water depths of 400-800 $\mathrm{m}$ and 1100-1400 m (Barcelona CFs) (Fig. 4A) and mounded, plastered, shallow-water contourites (Mallorca CFs) in a slope canyon near western Cabrera Island (southwest of Mallorca) at water depths of 250-600 m (Fig. 4B, Table II). A field of sediment waves is also present at the surface (Vandorpe et al., 2011; Lüdmann et al., 2012). Several plastered drifts of approximate $0.5 \mathrm{~s}$ thickness also occur around seamounts in the Valencia Trough at depths between $500 \mathrm{~m}$ and $>1100 \mathrm{~m}$ (Valencia CFs), in the southern Ibiza Channel and along the SE Iberian margins between depths of 600 and $900 \mathrm{~m}$ (Murcia CFs) (Fig. 3D, Table II). 
Downloaded from http://sp.lyellcollection.org/ at Consejo Superior De Investigaciones Cientificas (CSIC) on March 6, 2020

Contourites in the Alboran Sea display a great variety of both depositional and erosional features that range from a few to several tens of kilometres in length (Alboran CDS) (Fig. $5 A)$. Their morphologic and sedimentary characteristics have recently been described by Ercilla et al. (2016) and Juan et al. (2016). Depositional features predominate and are categorized as different types of drifts (Ercilla et al., 2002, 2012, 2016; Palomino et al., 2011; Juan et al., 2012, 2013, 2014, 2016). The largest drifts are plastered and sheeted types (Fig. 5B-C and 6A, Table II). Plastered drifts occur along the continental slopes of both the Iberian and African margins between water depths of 235 and 575-1000 m, respectively. These drifts appear in seismic images as upslope onlapping stratified facies that pinch out in both upslope and downslope directions (Fig. 5B and C). The sheeted drifts occur along the base of the central Iberian slope and in the western and southern Alboran basins at water depths below approximately $500 \mathrm{~m}$. These appear as parallel-stratified seismic layers with a subtabular geometry beneath a relatively flat seafloor (Fig. 6A). Several small plastered and sheeted drifts occur locally along the flanks and tops of seamounts (Fig. 5C). Smaller drifts include separated (Fig. 5B and 6B), channel-related (Fig. 6C) and mounded, confined drifts (Fig. 6D) (Palomino et al., 2010, 2011; Ercilla et al., 2012, 2016; Juan et al., 2012, 2013, 2014). Separated drifts occur along the westernmost upper and lower African slopes, and at the foot of structural seamounts and diapirs (Fig. 6B). In seismic images, they show onlapping stratified facies with internal discontinuities that display a mounded geometry. Channel-related drifts make up part of the seafloor within the Alboran Trough, appearing in the corridor between the Xauen bank and the African slope. Channel-related drifts consist of isolated irregular, stratified layers scattered within the channel floor (Fig. 6C). Confined drifts, situated between structural highs, display a mounded morphology, which consists of internally stratified layers (Fig. 6D).

The erosional contourite features are located primarily along the Alboran margin and consist of moats, scarps and furrows (Ercilla et al., 2016, and Juan et al., 2016). The moats are mostly associated with separated and confined drifts. A few incipient moats also occur along the walls of the structural highs, where the slope exhibits changes in bathymetric patterns (Fig. 5B and 6B). Scarps are narrow, steep erosional surfaces roughly parallel to the margin, which occur in association with landward flanks of terraces and other basal features along the slope. Scarps mark the transition between the basin's physiographic/oceanographic provinces. Furrows occur as linear features incised into steep, distal erosional escarpments of the African margin, near the Strait of Gibraltar. Extensive terraces represent mixed depositional and erosional features. These form the tops of plastered drifts along the continental slope. Terraces along the African margin are more pronounced (Fig. 5B). Terraces transition seaward into an onlapping, concordant surface. 
Downloaded from http://sp.lyellcollection.org/ at Consejo Superior De Investigaciones Cientificas (CSIC) on March 6, 2020

\subsection{Gulf of Cadiz}

\subsection{A. Oceanographic setting}

The modern hydrodynamic setting of the Gulf of Cadiz is dominated by the exchange of water between the Atlantic Ocean and Mediterranean Sea through the Strait of Gibraltar. This gateway allows egress of warm, saline Mediterranean Outflow Water (MOW), which flows into the Atlantic Ocean, and overlying inflow of the Atlantic Water into the Mediterranean Sea (Lacombe and Lizeray, 1959; Ochoa and Bray, 1991; Baringer and Price, 1999; Nelson et al., 1999; lorga and Lozier, 1999; Potter and Lozier, 2004; Lozier and Sindlinger, 2009) (Fig. 1 and Table I). The MOW is an intermediate water mass composed of waters originating in the Mediterranean Basin (Ambar and Howe, 1979; Bryden and Stommel, 1984; Bryden et al., 1994; Millot et al., 2006). The water mass accelerates through the narrow Strait of Gibraltar, reaching local velocities as high as $300 \mathrm{~cm} / \mathrm{s}$ (Ambar and Howe, 1979; Mulder et al., 2003) and moves northwestwards along the middle continental slope of the Gulf of Cadiz. This MOW flow occurs under the AIW and above the North Atlantic Deep Water (NADW). The AIW consists of the North Atlantic Superficial Water (NASW) from the surface down to a depth of approximately $100 \mathrm{~m}$ and the Eastern North Atlantic Central Water (ENACW), which flows between depths of 100 and $600 \mathrm{~m}$. In the Gulf of Cadiz, the Modified Antarctic Intermediate Water (AAIW) (Louarn and Morin, 2011) circulates above the MOW (Hernández-Molina et al., 2014b). The underlying NADW flows southwards from the Greenland-Norwegian Sea region at depths greater than $1500 \mathrm{~m}$ (Baringer and Price, 1999; Ambar et al., 1999; Serra et al., 2005).

In the Gulf of Cadiz, the MOW flow is controlled by the complex morphology of the continental slope. Flow is locally enhanced where salt tectonics have created diapiric ridges oblique to the MOW flow direction (Fig. 1). These ridges are partially responsible for splitting the MOW into numerous distinctive cores (Fig. 1), although vertical layering within the main MOW core has also been proposed as an alternative controlling mechanism (Sannino et al., 2007; Millot, 2009; Copard et al., 2011). The main water cores are the Mediterranean Upper Core (MU) and the Mediterranean Lower Core (ML), each of whose branches displays unique salinity, temperature and average velocity (Madelain, 1970; Zenk, 1975; Ambar and Howe, 1979; Gründlingh, 1981; Börenas et al., 2002; Serra et al., 2005) (Fig. 1). The MU flows along-slope along the southwestern Iberian margin at depths of 500-800 m, and part of its flow is captured by Portimão Canyon along the Algarve margin (Marchès et al., 2007). The ML generally flows northwestwards at an average velocity of $20-30 \mathrm{~cm} / \mathrm{s}$ (Llave at al., 2007 ) with the major part of flow concentrated west of $7^{\circ} \mathrm{W}$ (Madelain, 1970). At this longitude, a branch detaches from the south side of the $\mathrm{ML}$ and flows southwest. At approximately $7^{\circ} 20^{\prime} \mathrm{W}$, the $\mathrm{ML}$ divides into three distinct branches that generally flow 
Downloaded from http://sp.lyellcollection.org/ at Consejo Superior De Investigaciones Cientificas (CSIC) on March 6, 2020

northwest: the Southern Branch (SB), the Principal Branch (PB) and the Intermediate Branch (IB) (Fig. 1). Portimão Canyon and Cape St. Vincent also create a series of eddies, referred to as meddies due to their MOW origins (Ambar et al., 2002, 2008; Serra et al., 2005).

\subsection{B. Contourite features}

Erosional features are common in the Strait of Gibraltar, where high bottom current velocities prevent deposition (Kelling and Stanley, 1972; Stanley et al., 1975; Serrano et al., 2005). Esteras et al., (2000) identified several large channels likely associated with MOW circulation as the dominant contourite features. A few isolated plastered drifts also occur along the northern continental slope (Fig. 7A and B).

Beyond where the MOW exits the Strait of Gibraltar, its interaction with the middle slope of the southwestern Iberian margin has produced one of the most extensive and complex contourite depositional systems ever described. This feature is referred to as the Gulf of Cadiz CDS (Fig. 7, Table II) (e.g., Madelain, 1970; Kenyon and Belderson, 1973; Gonthier et al., 1984; Nelson et al., 1999; Llave et al., 2015; Stow et al., 2002a, 2002b, 2002c; Habgood et al., 2003; Hernández-Molina et al., 2006; Mulder et al., 2006; Hanquiez et al., 2007; Marchès et al., 2007; Roque et al., 2012; Brackenridge et al., 2013 and references therein). The main depositional features are sediment wave fields, sediment lobes, mixed drifts, plastered drifts, separated drifts and sheeted drifts. The major erosional features are contourite channels, furrows, marginal valleys and moats (García et al., 2009). All of these features occur at specific locations along the margin, and their distributions correspond to five morphosedimentary sectors within the CDS. Sector 1 includes proximal scours and ribbons. Sector 2 includes overflow sediment lobes. Sector 3 includes channels and ridges. Sector 4 includes contourite deposition and Sector 5 includes submarine canyons (Hernández-Molina et al., 2003, 2006; Llave et al., 2007). The development of each of these five sectors through time is related to an overall systematic deceleration of the MOW along the margin, with localised acceleration due to its interaction with irregularities along the seafloor. The middle slope of the Gulf of Cadiz is a bathymetrically complex area composed of mixed contourite features. This slope hosts four relatively flat contourite terraces with gradients of less than $0.5^{\circ}$ at average depths of $500,675,750$ and $850 \mathrm{~m}$ (García et al., 2009; Hernández-Molina et al., 2012, 2014b). These terraces are bounded by relatively steep risers with gradients of $1.5-3^{\circ}$. Terraces form by both depositional and erosional processes.

Four sets of separated drifts have been described at water depths of 500 to $700 \mathrm{~m}$ along the Algarve margin: the Faro-Albufeira, Portimão, Lagos and Sagres drifts (Table II). The Faro-Albufeira drifts are the most extensive and best developed. The Álvarez Cabral moat 
Downloaded from http://sp.lyellcollection.org/ at Consejo Superior De Investigaciones Cientificas (CSIC) on March 6, 2020

restricts these features to the upper slope. The drifts display asymmetric shapes and sigmoidal-oblique, prograding stacking patterns (Fig. 7C). These drifts rise 150-200 m above the adjacent moat axis and surrounding deposits, and grade southwards into the Faro and the Bartolomeu Dias sheeted drifts, where the seafloor is smooth and almost flat (Fig. 7D). The Portimão and Lagos drifts extend approximately $50 \mathrm{~km}$ from Portimão Canyon but are separated by Lagos Canyon. These display a smooth mounded morphology and categorize as sheeted drifts (Hernández-Molina et al., 2003; Marchès et al., 2007, 2010). However, Roque et al. (2012) reported that the Lagos drift grades from a sheeted drift near Lagos Canyon to a plastered drift near the San Vicente high and finally to a separated drift. The Sagres drift occurs at the transition between the southern and western Portuguese margins.

Sheeted drifts, with an aggrading stacking pattern and gentle morphology, occur between water depths of 600 and $1600 \mathrm{~m}$ in the contourite depositional and submarine canyons sectors (Vanney and Mougenot, 1981). These were deposited across hundreds of kilometres, over which they are crossed by diapiric ridges, deformed and eroded by large contouritic channels of Sector 3 (channels and ridges sector) (Fig. 8A-C) (García, 2002; Mulder et al., 2002, 2003; Habgood et al., 2003; Hernández-Molina et al., 2003, 2006; Llave, 2003; Llave et al., 2007).

Extensive bedforms include ripple marks, sand ribbons and sediment waves (Fig. 8D). Longitudinal mounded drifts (Fig. 9A) are well developed in a NW-SE direction in Sector 1 (proximal scours and ribbons sector) and in Sector 2 (overflow sediment lobes sector) (Hernández-Molina et al., 2006; Llave et al., 2007).

Composite erosional features occur along the Guadalquivir Bank. Along with numerous diapiric highs (isolated and ridge-form), these include four types of submarine valleys (moats, channels, marginal valleys and furrows) in Sector 3 (García, 2002; HernándezMolina et al., 2003, 2006; García et al., 2009) (Fig. 9). The main erosional features along the middle slope of the central Gulf of Cadiz (Sector 3 ) include five major contourite channels (Fig. 8A-C). These occur along the southern flanks of the diapiric ridges and the Guadalquivir Bank. They include (from north to south) the Diego Cao, Huelva, Gusano, Guadalquivir and Cadiz Contourite channels (García et al., 2009). Different channels assume different dimensions but all display sinuous trends in the down-slope to along-slope directions. The Cadiz and Guadalquivir channels (Fig. 8A) represent the largest features (1 and $12 \mathrm{~km}$ wide, respectively, more than $100 \mathrm{~km}$ long, up to $130 \mathrm{~m}$ deep). Marginal valleys are unique erosional features located along northwest sides of the diapiric ridges and isolated diapirs within the channels and ridges sector (Fig. 9E). These features exhibit irregular orientations but a locally sinuous morphology with a predominantly NE-SW trend 
Downloaded from http://sp.lyellcollection.org/ at Consejo Superior De Investigaciones Cientificas (CSIC) on March 6, 2020

(García et al., 2009). Their incision depths can exceed $250 \mathrm{~m}$ at some localities. The most prominent example of these features in the Gulf of Cadiz is the Alvarez Cabral contourite moat (Fig. 7C), which is associated with the Faro-Albufeira mounded drifts (Sector 4) (Gonthier et al., 1984; Llave et al., 2001; García, 2002; Stow et al., 2002c; HernándezMolina et al., 2003, 2006; Marchès et al., 2007). This moat (80 km long, 3.5-11 km wide) incises the base of the Algarve margin's upper slope and trends WSW, parallel to the slope.

Sector 1, located at water depths of between 500 and $1000 \mathrm{~m}$, is where the majority of the erosional features occur. This locality hosts abrasive surfaces (Fig. 9B) and several NWSE-trending erosional scours (Fig. 9C) formed across an extensive area (90 km long and 30 km wide) (Kenyon and Belderson, 1973; Habgood, 2002; Hernández-Molina et al., 2003, 2006). This sector also hosts two main channels (Fig. 9A) (Hernández-Molina et al., 2012, 2014b). The southern channel forms due to WSW-trending erosion from the Camarinal Sill and at 3-4 km width, represents the most significant erosional feature near the Strait of Gibraltar. The northern channel is obscured by infill near the Strait but becomes more distinct towards the northwest, where it joins the Cadiz and Guadalquivir contourite channels (Hernández-Molina et al., 2014b). Both southern and northern channels host an associated mounded drift along the seaward side of the channel and numerous small oblique furrows (Fig. 9A) (Hernández-Molina et al., 2014b). Several reports have interpreted furrows in the overflow sedimentary lobe sector (Sector 2) as erosional features related MOW dynamics and gravitational processes (Habgood et al., 2003; Mulder et al., 2003; Hanquiez et al., 2007; García et al., 2009). The best-developed furrow is the Gil Eanes furrow (Fig. 9D), situated at water depths between 900 and $1200 \mathrm{~m}$. Kenyon and Belderson (1973) first described this feature while Habgood et al. (2003), Hanquiez et al. (2007) and García et al. (2009) published subsequent descriptions. The furrow is approximately $50 \mathrm{~km}$ long and has a width of 0.8-1.7 km, a sinuous trend, and erosional incision of up $90 \mathrm{~m}$.

\subsection{West Iberia}

\subsection{A. Oceanographic setting}

Four main water masses flow along the western Iberian margin at different depths (Fig. 1 and Table I). As the main shallow currents, (1) the Portugal Current (PC) flows southward while the Portugal Coastal Current (PCC) flows towards the north (Fiúza et al., 1998; Pérez et al., 2001; Martins et al., 2002; Peliz et al., 2005; Varela et al., 2005). The ENACW (2) of subtropical origin extends down to water depths of $600 \mathrm{~m}$ (McCartney and Talley, 1982; Fiúza, 1984; Pollard and Pu, 1985; Ambar and Fiúza, 1994; Fiúza et al., 1998; Perez et al., 2001) and moves north from about 200-300 m. A component of ENACW of subpolar origin moves south from about 300-400 m (Ambar and Fiuza, 1994; Fiúza et al., 1998). After 
exiting the Gulf of Cadiz, the MOW (3) splits into three principal branches: a main branch flowing northwards, a second branch flowing westwards and a third branch flowing southwards towards the Canary Islands before veering westwards (Ambar and Howe, 1979; lorga and Lozier, 1999; Slater, 2003). The northern branch flows along the middle slope of the Portuguese margin towards the Galician margin and the Bay of Biscay. This branch includes two distinct cores centred at water depths of $800 \mathrm{~m}$ and nearly $1200 \mathrm{~m}$. Along the Oporto continental slope, the MOW mixes with the ENACW flowing at depths between 250 and $540 \mathrm{~m}$. At approximately $42^{\circ} \mathrm{N}$, the MOW bifurcates intermittently into two branches (Mazé et al., 1997). Of these, one branch flows west of the Galicia Bank plateau and the other flows north along the continental slope of the Iberian Peninsula (lorga and Lozier, 1999; González-Pola, 2006). The deep-water masses (below 2000-m water depth) of the western Iberian margin consist of the southwards-flowing NADW and northwards-flowing Lower Deep Water (LDW) (4) (van Aken, 2000). This LDW forms primarily from the mixing of the deep Antarctic Bottom Water (AABW) and the Labrador Deep Water (LADW) (Le Floch, 1969; Botas et al., 1989; Haynes and Barton, 1990; McCartney, 1992; Pingree and Le Cann, 1990; Van Aken, 2000; McCave et al., 2001; Valencia et al., 2004).

\subsection{B. Contourite features}

The Sines drift (a separated drift) represents the main contourite depositional feature of western Iberia. Mougenot (1989) first identified this feature as a contourite based on its general mounded morphology and wavy seismic patterns (Fig. 10A and B, Table II). The Sines drift is bounded by two of the Portuguese margin's major canyons: Setúbal Canyon to the north and San Vicente Canyon to the south (Fig. 10A). Formed by MOW circulation, the drift is an elongated, plastered sedimentary body formed below $750 \mathrm{~m}$ water depth along the gentle $\left(\sim 0.5^{\circ}\right) \mathrm{N}$-S trending continental slope of the Alentejo margin (AM) (Fig. 10B). Roque et al., (2015) recently discovered an extensive area (approximately $52 \mathrm{~km}$ long and $34 \mathrm{~km}$ wide) of the Sines drift affected by slope failure and mass wasting.

Recent reports have documented additional local contourite features occurring around structural highs and topographic irregularities associated with the circulation of either the MOW (300-2000-m water depth) or LDW (>2000-m water depth). Roque et al. (2015) recently identified a new separated drift offshore of Aveiro on the continental rise at a water depths of approximately 2500 m (Fig. 10C, Table II. Neves et al. (2009) reported evidence of a contourite between water depths of 2300 and $3000 \mathrm{~m}$ reaching approximately $1.5 \mathrm{~s}$ thickness and $2.5 \mathrm{~km}$ width. This contourite drift is separated from a structural high by a moat (Fig. 10C). Large-scale sediment waves also appear in high-resolution seismic 
Downloaded from http://sp.lyellcollection.org/ at Consejo Superior De Investigaciones Cientificas (CSIC) on March 6, 2020

reflection data (Fig. 10D), along with localised synsedimentary deformation and primary faulting within contourite drift strata (Alves et al., 2000, 2003).

Clear examples of both depositional (plastered drift, separated drift, sediment waves) and erosional (terraces, moats, furrows) features occur along the Galician continental margin and rise (Galicia Bank CFs) (Ercilla et al., 2006, 2008a, 2009, 2011; Bender et al., 2012; Hanebuth et al., 2015; Llave et al., 2018; Collart et al., 2018). The plastered drifts occur as low-relief mounds of a few kilometres in length, and tens to a few hundred metres in thickness. Their internal structure as revealed by high to very high amplitude acoustic reflections highlights well-stratified, aggradational-progadational seismic features of good lateral continuity (Fig. 10E, Table II). Plastered drifts along the continental slope occur: i) on the northwestern flank (2100 m water depth), ii) along the northern scarp (1600 m water depth), iii) at the base of certain structural highs (between 1500 and $4980 \mathrm{~m}$ deep) within the Galicia Bank plateau (Ercilla et al., 2011) and iv) along the distal part of the Ortegal marginal platform (OMP) between water depths of 700 and 1100 m (Fig. 10E) (Jané et al., 2012; Llave et al., 2013, 2018). These drifts display smooth and terraced morphology (Ortegal $C D S$ ), a morphology which contrasts the numerous adjacent submarine canyons incised into the seafloor.

Major separated drifts occur at four locations. The first location lies along the lower continental slope of the western Galician continental margin, specifically at the foot of and near highs reaching approximately 2000 m water depth (Ercilla et al., 2006; Bender et al., 2012). Sediment waves contour the surface of this drift. The second drift occurs in the Transitional Zone (TZ: 1600 to 2500 m) (Ercilla et al., 2011). A third occurs along the Galicia Bank plateau (GB: 700-800-m water depth), where several moats and associated drifts (15 to $250 \mathrm{~m}$ tall from the moat axis to the top of the drift crest and $1-5 \mathrm{~km}$ wide) are developed at its foot and around the numerous highs (Fig. 11A). Elongated separated drifts have formed on one flank adjacent to three of the aforementioned highs while local plastered drifts form on the other flank (Ercilla et al., 2008a, 2011a). As such, these separated drifts form part of the Galicia Bank CFs. The fourth separated drift locality occurs at the heads of Ferrol and A Coruña canyons at water depths of 500 and $700 \mathrm{~m}$, and as part of the Pardo Bazán marginal platform at a depth of $1600 \mathrm{~m}$ in the Ortegal CFs (Fig. 11B). These drifts exhibit mounded shapes and are 5-22 km long, 2-10 km wide and average $50 \mathrm{~m}$ in thickness (Jané et al., 2012; Llave et al., 2013, 2018; Collart et al., 2018). A separated drift occurs at the foot of the highs across the lower slope of the western Galician continental margin (Bender et al., 2012). Several of these drifts host sediment waves, which are also developed at the heads of Ferrol and A Coruña canyons (Jané et al., 2012; Llave et al., 2018; Collart et al., 2018). 
Downloaded from http://sp.lyellcollection.org/ at Consejo Superior De Investigaciones Cientificas (CSIC) on March 6, 2020

Abraded surfaces are tens of metres in relief and several hundreds of metres long. Seismic images show reflectors for these features terminating against eroded seafloor surfaces that form large-scale contourite terraces. The main abraded surfaces occur along the Ortegal, Pardo Bazán and Castro marginal platforms (OMP, PBMP and CMP respectively) where they form three contourite terraces at water depths of 200-600 m, 900$1800 \mathrm{~m}$, and 2000-3500 m, respectively (Ortegal CDS) (Fig. 11C) (Jane et al., 2012; Llave et al., 2018). These represent structural highs (Fig. 11D) (Ercilla et al., 2008a, 2011). The Ortegal terrace is the most extensive of these highs, spanning approximately $150 \mathrm{~km}$ in length, up to $70 \mathrm{~km}$ in width to the north and approximately $20 \mathrm{~km}$ width in the south (Llave et al., 2013, 2018). Moats are erosional features that typically occur at the foot of structural scarps and highs (Fig. 11A). These can represent tens of metres (depth) and hundreds of metres (width) of erosional incision. Their asymmetric, V-shaped cross-sections exhibit steeper eastern margins (Ercilla et al., 2011). Several moats occur on the Ortegal terrace and at the heads of Ferrol and A Coruña Canyons (Fig. 11B) (Jané et al., 2012; Llave et al., 2013, 2018; Collart et al., 2018).

Older contourite deposits may also occur along the western Iberian margin, particularly within the Iberian abyssal plain (southern Galicia Bank CFs). Sediment waves occur within the upper rise according to Miocene through Quaternary sediments drilled at ODP Site 1069 (Whitmarsh et al., 1998) and according to middle Eocene deposits offshore of Oporto, drilled by ODP Leg 149 and in the DSDP Leg 48B area (Wilson et al., 1996, 2001). Soares et al. (2014) have described several Cretaceous drifts consisting of elongated mounded drifts along the outer proximal margin. These workers inferred the presence of sheeted drifts along the distal margin offshore of northwest Portugal deposited after the Aptian-Albian lithospheric breakup. Near the continental margin of the Galicia Bank, deposits drilled by ODP-Leg 103 (Boillot et al., 1987; Comas and Maldonado, 1988), DSDP-Leg 47B Site 398 along the southern margin of the Vigo Seamount (Maldonado, 1979), and ODP-Leg 149 Sites 897 through 901 (Alonso et al., 1996; Milkert et al., 1996), were also interpreted as contourites deposited in the late Miocene.

\subsection{Cantabrian margin}

\subsection{A. Oceanographic setting}

Along the Cantabrian continental margin, most of the water masses originate in the North Atlantic or result from interactions between waters originating in the Atlantic and Mediterranean. The uppermost water mass is the ENACW, which extends to depths of approximately 400 to $600 \mathrm{~m}$ and flows westwards along the continental margin (Fig. 1 and Table I) (González-Pola, 2006). It generally flows at a velocity of $1 \mathrm{~cm} / \mathrm{s}$, although it can 
Downloaded from http://sp.lyellcollection.org/ at Consejo Superior De Investigaciones Cientificas (CSIC) on March 6, 2020

occasionally reach velocities of up to $10 \mathrm{~cm} / \mathrm{s}$ (Pingree and Le Cann, 1990). Between water depths of $400-500$ and $1500 \mathrm{~m}$, the MOW follows the continental slope as a contour current (Fig. 1). Seafloor irregularities and the Coriolis effect control the local MOW circulation. Although detailed information is lacking on MOW circulation in the Bay of Biscay, it appears to split into two branches around the Galicia Bank. One of these continues northwards while the other flows eastwards along the Cantabrian margin slope (lorga and Lozier, 1999; González-Pola, 2006). From Ortegal Spur to Santander, the MOW propagates along the slope at reduced velocities. Its minimum velocity is around $2-3 \mathrm{~cm} / \mathrm{s}$ at $8^{\circ} \mathrm{W}$ and $6^{\circ} \mathrm{W}$ (Pingree and Le Cann, 1990; Diaz del Rio et al., 1998). The NADW occurs between water depths of 1500 and 3000 m (Fig. 1) and includes a core of LSW at a depth of approximately 1800 m (Vangriesheim and Khripounoff, 1990; McCartney, 1992). The LDW forms beneath the NADW primarily due to mixing of the deep AABW and the LSW (Botas et al., 1989; Haynes and Barton, 1990; McCartney, 1992) (Fig. 1). A cyclonic recirculation cell develops over the Biscay abyssal plain. This feature exhibits a characteristic polewards velocity near the continental margin of $1.2( \pm 1.0) \mathrm{cm} / \mathrm{s}$ (Dickson et al., 1985; Paillet and Mercier, 1997).

\subsection{B. Contourite features}

The Le Danois CDS has been identified along the Cantabrian margin (Fig. 12, Table II) in an area surrounded predominantly by down-slope processes (Ercilla et al., 2008b; Iglesias, 2009; Van Rooij et al., 2010). This CDS includes both depositional and erosional features (separated drifts, plastered drifts, moats and scours) generated by the MOW circulation and controlled by seafloor irregularities including two topographic highs, the large Le Danois Bank and the smaller Vizco High (Fig. 12A) (Van Rooij et al., 2010).

The Le Danois CDS includes two separated drifts: the Gijón and Le Danois drifts. The Gijon drift occurs along the upper slope at water depths of approximately $400-850 \mathrm{~m}$ and has a maximum thickness of $0.25 \mathrm{~s}$ (Fig. 12B, Table II). The Le Danois drift occurs at the foot of the southern/side of the Le Danois Bank at water depths between 800 and 1500-1600 m. This feature is approximately $0.3 \mathrm{~s}$ thick and varies in width, reaching as much as $10 \mathrm{~km}$ width in its central part but only spanning 3.5 to $4 \mathrm{~km}$ to the west and $4.7 \mathrm{~km}$ to the east (Fig. 12B). Three plastered drifts of about $1 \mathrm{~s}$ thickness occur along the upper, southern slope of the Le Danois Bank (Van Rooij et al., 2010). These appear as mounded relief along the western edge between water depths of 600 and $750 \mathrm{~m}$ and on the eastern edge at depths of 750-1100 $\mathrm{m}$ and 1100-1550 m (Fig. 12C, Table II).

Moats and scours are the main erosional features of the Le Danois CDS. The two moats identified are referred to as the Gijón and Le Danois moats. As the upslope continuation of Gijón Canyon, the Gijón moat trends NW-SE and spans approximately 45 km length and 1-4 
$\mathrm{km}$ width. This feature begins at $1100 \mathrm{~m}$ water depth, incises an additional $400 \mathrm{~m}$ in the west and disappears to the east (Fig. 12B). The Le Danois moat trends in a WNW-ESE direction and extends from depths of 800 to $1500 \mathrm{~m}$ towards the east. It spans $48 \mathrm{~km}$ in length, varies from 0.8 to $2.8 \mathrm{~km}$ in width and incises $75-105 \mathrm{~m}$ of surface (Fig. 12B). Scour alignments trending NE and ENE occur on one of the plastered drifts. These span 5.5-28 km in length, $1250 \mathrm{~m}$ in width and run $\sim 5 \mathrm{~m}$ deep (Van Rooij et al., 2010).

\subsection{Sedimentology of contourite features}

Contourite deposits along the Iberian margin range in grain size from clay to sand but primarily categorize as mud-rich. Deposits include thin, interbedded layers of fine-grained sand and silt of terrigenous and biogenic origin. The fine-grained beds are predominantly poorly sorted, intensely bioturbated and typically display broad rhythmic bedding (Stow et al., 2002a, b).

Gonthier et al. (1984) and Faugères et al. (1984) proposed the original contourite facies model sequence based on research across the Faro drift along the middle slope of the Gulf of Cadiz. Their model consists of two superposed units, including a basal coarsening-upward unit grading from homogeneous mud (clay, fine silt) to mottled coarser silt and finally to sandy silt/silty sand. This is followed by a fining-upward unit with an inverse facies succession. This general 'bigradational' model theoretically represents an increase bottom current flow followed by a decline in current strength (Stow and Holbrook, 1984; Stow et al., 2002c; Huneke and Stow, 2008). Stow and Faugères (2008) extended this model to include five sedimentary divisions applied to the standard bigradational contourite sequence (C1-C5) (Fig. 13). The model can be applied to contourites of siliciclastic, volcanic, bioclastic or mixed composition. Bioturbation limits preservation of sedimentary structures but indistinct to discontinuous parallel laminations, coarser sand layers or rare cross laminations may occur. The facies model interprets the bigradational sequence as two shifts in the strength of the bottom-current flow: from weak to strong, and then back to weak. The continued presence of coarsening/fining upwards trends in grain size along with strong bioturbation and mottling indicates continuous, gradual (relative to gravity flow deposits) deposition of sediments through bottom current processes. As the velocity increases, coarser sediment predominates as removal of the fine fraction produces coarser, better sorted sedimentary packages (Nelson et al., 1993). Stow and Faugères (2008) also described sandy contourites that contain an inversely graded lower sub-sequence (mud + mottled silt and mud units), a middle sandy silt and an upper, normally graded sub-sequence (mottled silt and mud + mud units). Most of these deposits were interpreted as bottom current-modified turbidites (Faugères and Stow, 1993, 2008; Stow et al., 2002b, c; Stow and Faugères, 2008). Mulder et al. (2013) concluded that contourite sequences record changes in bottom current velocity 
Downloaded from http://sp.lyellcollection.org/ at Consejo Superior De Investigaciones Cientificas (CSIC) on March 6, 2020

and flow competency but may also depend on sediment supply. These workers hypothesized that increased erosion of mud along the flanks of confined contourite channels and moats or increases in sediment supply by rivers and down-slope mass transport along the continental shelf and upper slope provided the coarse, terrigenous sediment observed.

Coarse terrigenous sediment is significant in the Gulf of Cadiz. Research from IODP Expedition 339 and other cores from other cruises have detected voluminous, mature and well to moderately sorted contourite sands that form laterally extensive sheeted drifts, channel-floor cover or patch drifts in contourite channels (Buitrago et al., 2001; Viana et al., 2007; Hanquiez, 2006; Hanquiez et al., 2007; Viana, 2008; Stow et al., 2011a, 2011b, 2013a; Brackenridge et al., 2013; Hernández-Molina et al., 2014a, 2014b, Brackenridge et al., 2018).

The Ortegal Spur of the Ortegal contourite terrace (Llave et al., 2013) also hosts compositionally mature, coarse and silty sands. Sands specifically consist of subrounded and well-sorted quartz and glauconite grains with abundant bioclastic fragments. The bioclasts include fragments of foraminifera, gastropods, bivalves and pteropods (Alejo et al., 2012).

\subsection{Translating seismic facies to sedimentary facies}

Contourite features are described and systematised here according to their seismic characteristics. Interpretations therefore depend heavily on external drift morphology, internal stacking pattern of depositional units and other aspects apparent in seismic images. Local and regional water circulation patterns and paleoceanographic models support these interpretations.

Drift morphologies (i.e., separated, sheeted, plastered and confined drifts) are recognized at the scale of the drifts themselves (Fig. 14). Slope-plastered contourite drifts predominate upper slope settings. These often occur in the presence of elongated erosional surfaces along the uppermost slope and in downslope areas, accompanied by a mounded alongslope elongated drift, with frequent sediment waves and internal erosional surfaces (Fig. 14). In middle and lower slope areas, complex seafloor physiography caused by tectonics creates obstacles for current flow. These features induce local acceleration and create a considerable variety of drifts and erosional features such as moats, channels and furrows (Fig. 14). Middle and lower slope areas also host contourite terraces, which form from both depositional and erosional processes (Fig. 14).

Depositional units within contourites reported around Iberia are generally lenticular in shape, and have a well-layered, convex-up seismic units of good lateral continuity along 
Downloaded from http://sp.lyellcollection.org/ at Consejo Superior De Investigaciones Cientificas (CSIC) on March 6, 2020

both strike and dip (Figs. 2-12). Stacking patterns show downlapping (onlapping on steep slopes) and sigmoidal progradational reflector patterns where downstream and upslope migration occurred (Figs. 2-12).

Table III lists seismic facies most commonly recognized from Iberian contourite drifts. Among these are: (a) transparent layers of variable thickness intercalated with zones of high to moderate amplitude seismic reflectors, particularly in sheeted drifts (Figs. 6A, 7D, 8A-C), (b) smooth, parallel, moderate to high amplitude reflectors typically interbedded with transparent zones in plastered drifts and common throughout mounded, confined and channel-related drifts (Figs. 2B, 3A-D, 4A-B, 5B-C, 6B-D, 7C 9A, 10 B-C, 11A-B and 12B-C). Discontinuous seismic facies include short, discontinuous to chaotic reflectors (c) of moderate to high amplitude occurring in most drifts, particularly in mounded drifts and moats (Figs. 2A, 3A-and 3D, 6B-C, 7C, 9A, 10C, 11A, 12B). Sigmoid progradational reflectors (d) occur in mounded drifts where strong downstream and/or oblique migration has occurred. They are also common in separated drifts (Figs. 3B, 7C, 12B). Gently wavy reflectors (e) are common over parts of several drifts (Figs. 3C, 8D, 10D). Contourite terraces and practically all contourite depositional systems host horizontal and low-inclination (f) reflectors truncated at the seafloor or by an internal erosional surfaces (e.g. Figs. 4A-B, 5B, 9A-B, 11B-C).

Relatively uniform deposits (fine or coarse sediments) tend to exhibit transparent or weak seismic facies whereas extensive sheets of interbedded coarse- and fine-grained sediments exhibit higher amplitude seismic reflectors with good lateral continuity. The aforementioned laterally extensive progradational to aggradational seismic units with sub-parallel, variable amplitude reflectors indicate muddy compositions. By contrast, moats within contourite channels and many contourite terraces exhibit High Amplitude Reflections (HARs). These high amplitude seismic reflections span a few kilometers in width and are interpreted as coarse-grained sediments (Deptuck et al., 2003; Posamentier and Kolia, 2003). These facies occur in erosional features such as moats and along channels axes (Table III), which develop in channels around seafloor irregularities. Contourite terraces (e.g., Alboran, Gulf of Cadiz, WIM, Ortegal) (Fig. 14 and Table III) and overflow features can also appear as HAR seismic facies. The Gulf of Cadiz' proximal Sector 1 is an example of an overflow feature where an exceptionally thick sandy sheeted drift appears as an extensive HAR unit (Fig. 14).

Contourite features described here occur at depths corresponding to the principal interfaces between MAW-LIW-WMDW in the Western Mediterranean Sea, and between the ENACW- MOW-NADW in the Atlantic. The HARs however do not appear to correspond with enhanced bottom currents, development of terraces on top of plastered drifts or bottom current modification of sand layers exposed at the seafloor surface. Their origin and 
Downloaded from http://sp.lyellcollection.org/ at Consejo Superior De Investigaciones Cientificas (CSIC) on March 6, 2020

interpretation remain unresolved in spite of their economic potential as hydrocarbon reservoirs.

\section{DISCUSSION}

\subsection{Factors influencing contourite seismic/sedimentary facies changes}

Contourite drifts along the Iberian margin exhibit certain stratigraphic patterns in their reflection amplitudes (Figs. 2-12). These patterns include a more transparent facies (T) at the base, higher amplitude reflections $(R)$ in the upper part and a subtle but continuous highamplitude erosional surface at the top. In the case of the Faro Drift (Gulf of Cadiz) these variations have been attributed to long-term changes in bottom-current strength at different scales through the latest Pliocene and Quaternary (Llave et al., 2001; Stow et al., 2002a, 2002b, 2002c; Hernández-Molina et al., 2016b). This mechanism creates repeated coarsening-upward sequences bounded by erosional surfaces at unit and sub-unit scales.

In the case of the Gulf of Cadiz CDS, several studies interpreted these facies as reflecting changes in MOW bottom current strength (e.g., Gonthier et al., 1984; Faugères et al., 1985a; Stow et al., 1986, 2002c; Sierro et al., 1999; Roque et al., 2012) linked to eustatic/climatic drivers and MOW variability (Voelker et al., 2006; Toucanne et al., 2007; García et al., 2009; Rogerson et al., 2012; Bahr et al., 2014; Hernández-Molina et al., 2014a). IODP Expedition 339 sampled some of the Gulf of Cadiz CDS seismic facies and found that transparent seismic facies corresponded to fine-grained contourites while HARs corresponded to mature, well-sorted contourite sands that reached up to $10 \mathrm{~m}$ in thickness (Stow et al., 2013b; Hernández-Molina et al., 2014b, 2016b).

Interacting factors determine the degree to which bottom currents can influence the morphology of the Iberian margin. At longer time scales, tectonic factors determine the role that downslope sediment transport plays in margin development. Tectonics also influence contourite sedimentation as the mechanism producing remnant marginal platforms, structural highs and the opening of the Gibraltar Strait itself (i.e., northwestern Iberian margins, Maestro et al., 2015; Llave et al., 2018). On shorter time scales, climate and sealevel changes cause deepening or shoaling of water masses. This in turn controls the vertical distribution of sand and mud deposits, associated acoustic facies, stratigraphic stacking patterns and thicknesses. Climate and sea-level changes also drive the general behavior of the water masses and influence depositional styles along the margins. In the Gulf of Cadiz and west of Iberia, Mediterranean water masses flowed more swiftly and at greater depths during glacial periods (Schönfeld and Zahn, 2000; Rogerson et al., 2005; Llave et al., 2006; Voelker et al., 2006; Ercilla et al., 2016). This would favor local 
Downloaded from http://sp.lyellcollection.org/ at Consejo Superior De Investigaciones Cientificas (CSIC) on March 6, 2020

development of sandy contourites at intermediate to lower water depths along the continental slope. These factors explain the Iberian margin's overall sedimentary evolution from dominantly downslope or mixed along-slope/down-slope sedimentary processes at the beginning of the Pliocene to more along-slope sedimentation with the Quaternary opening of the Strait of Gibraltar (Roque et al., 2012; Brackendridge et al., 2013; Hernández-Molina et al., 2016b; Ercilla et al., 2016).

The relationship between oceanographic processes and the depositional, erosional and mixed features observed among Pliocene and Quaternary contourites allows for interpretation of similar features in the ancient record. Ancient oceans consisted of different water masses and circulation regimes than those observed today (e.g., Hay, 2009). The most discernible patterns belong to extreme glacial maxima and greenhouse conditions (Pickering and Hiscott, 2016). Records left by ancient water masses should nevertheless resemble sandy and muddy deposits described here.

\subsection{Implications for petroleum exploration}

Thick and widespread progradational to aggradational depositional units characterized by sub-parallel reflectors of varying amplitude in seismic images are interpreted to represent fine-grained drifts occurring throughout the Iberian margin. Continuous high-amplitude reflections (HARs) indicative of sandier contourites occur in moats and channels, in contourite terraces and in sectors with sheeted drifts affected by overflows. IODP Expedition 339 drilled several of these drifts around the Gulf of Cadiz and western Iberian Margin. These features exhibit seismic facies similar to those observed in other sectors of the Iberian margin. Sampling of these drifts showed that sub-parallel reflectors of variable amplitude corresponded to muddy contourites that were sometimes enriched in organic carbon (up to 2 wt.\%). These units could therefore serve as both seals and potential source rocks (Stow et al., 2013b; Hernández-Molina et al., 2013). Sampling of seismic features associated with sandy contourites also suggests extensive distribution of mature, well-sorted Pliocene to Quaternary sands (Expedition 339 Scientists, 2012; Stow et al., 2013b; Hernández-Molina et al., 2013). HARs indicate sandy contourites for example, in southeasterly areas of the Gulf of Cadiz (affected by the overflow processes), where Brackenridge et al. $(2013,2018)$ identified a tabular, aggradational sedimentary stacking pattern associated with a buried, mixed, contourite-turbidite succession. This feature includes a sand- and clay-rich interval between 925 and $1740 \mathrm{~m}$ reaching 815 metres thickness. With $600 \mathrm{~m}$ of sand alone, this contourite could serve as a potential reservoir unit (Buitrago et al., 2001; García-Mojonero and Olmo, 2001). Cakebread-Brown et al. (2003) have also interpreted HARs and AVO anomalies from this unit as high-porosity (30\%), gas-bearing contourite sands. 
The Santos Drift in the northern Santos Basin includes $>600 \mathrm{~m}$ of fine-grained Neogeneaged sand and silt and thus acts as seal rock for Paleogene oil-bearing sandstones (Duarte and Viana 2007). Similar sandy contourites have been described along the Uruguayan margin (Hernández-Molina et al., 2016c), within the Pliocene sedimentary record of the Gulf of Mexico (Shanmugam et al., 1993), in Eocene deposits of the Campos Basin, Brazil (Mutti et al., 1980; Viana and Rebesco, 2007) and in the northeastern Atlantic (Nelson et al., 1993; Howe et al., 1994; García-Mojonero and Martínez del Olmo, 2001; Habgood et al., 2003; Stow et al., 2002a, 2002b, 2013a, 2013b; Akhmetzhanov et al., 2007; Hernández-Molina et al., 2014a, 2014b). In these cases, HARs record contourite deposits mainly composed of medium- to fine-grained sand with common bedforms, such as mega-ripples and sand waves (Viana et al., 1998, 2002; Stoker et al., 1998; Masson et al., 2004; Shanmugam, 2006, 2012a, 2013b; Mutti and Carminatti, 2012).

Similarities between these features and those described from the Gulf of Cadiz (Hernández-Molina et al., 2016b) and Iberian continental margin indicate the economic potential of sandy contourites from these areas. The occurrence of coarse to fine grained sedimentary materials associated with contourites around Iberia could inform interpretation of deeper-water sedimentary facies from the ancient record. Emerging information on contourites could also facilitate innovations in deep-water petroleum exploration strategies.

\section{CONCLUSIONS AND FUTURE AREAS OF STUDY}

Contourite features of the Iberian continental margin include extensive depositional, erosional and mixed (depositional and erosional) features developed along the continental slope due to bottom current dynamics. Depositional features include mounded, elongated and separated, sheeted, plastered, confined and channel-related drifts. Erosional features include moats, channels and furrows while terraces are interpreted as mixed erosional/depositional features. Large muddominated contourite drifts with good, along-slope continuity could serve as petroleum source rocks. Moats, channels and sheeted drifts proximal to overflows and contourite terraces exhibit high amplitude reflections (HARs) in seismic images. These are interpreted as extensive sandy contourites that could also serve as potential hydrocarbon reservoirs.

The muddy/sandy contourites described here, along with the overall deep water morphology of the Iberian margin generally record intermediate to deep water masses and their interfaces from the Pliocene to Quaternary. The connection between observed features and mechanisms makes these features good analogs for 
Downloaded from http://sp.lyellcollection.org/ at Consejo Superior De Investigaciones Cientificas (CSIC) on March 6, 2020

interpreting recent or ancient deep water environments and useful in identifying potential seals and reservoir rocks. Similar contourite features in deeper or older sediments could represent future petroleum exploration opportunities. Advances in geophysics, offshore 3D seismic imaging and robust correlation with well-log and borehole data will help further understanding of contourites and their role in petroleum systems.

\section{ACKNOWLEDGEMENTS}

This contribution is a product of the IGCP-619 and INQUA-1204 projects and is partially supported through the CTM 2008-06399-C04/MAR (CONTOURIBER), CGL2011-16057-E (MOW), CTM 2012-39599-C03 (MOWER), CGL2016-80445-R (SCORE), FCT-PTDC/GEOGEO/4430/2012 (CONDRIBER), CTM2016-75129-C3-1-R and CGL2015-74216-JIN projects. The research was conducted in the framework of "The Drifters Research Group" of the Royal Holloway University of London (UK). Thanks to SECEG and SNED for permission to include a seismic profile obtained during an oceanographic cruise in the Strait of Gibraltar (Fig. 7B), and to ECOMARG Project, providing the multibeam bathymetry data obtained in Le Danois or "El Cachucho" (Fig. 11A). We thanks the editor Dr. Ken McClay and the two reviewers, Dr. Domenico Chiarella and Anonymous, for their positive and useful comments, which have improved the original submitted version.

\section{REFERENCES}

Akhmetzhanov, A., Kenyon, N.H., Habgood, E., Van Der Mollen, A.S., Neilsen, T., Ivanov M., Shashkin, P., 2007. North Atlantic contourite sand channels. In: Viana, A.R., Rebesco, M. (Eds.), Economic and Palaeoceanographic Significance of Contourite Deposits. Geological Society of London, Special Publication 276 (1), 25-47.

Alejo, I., Nombela, M.A., Ercilla, G., Brackenridge, R.E., Francés, G., Pérez-Arlucea, M., Mena, A., Hernández-Molina, F.J., Stow, D.A.V., Medialdea, T., 2012.Caracterización de los sedimentos superficiales en tres sistemas deposicionales contorníticos (Golfo de Cádiz, Cabo Ortegal y El Cachucho): implicaciones conceptuales. Resúmenes extendidos del VIII, Congreso Geológico de España. Geo-Temas 13, 1781-1784.

Alonso, B., Comas, M.C., Ercilla, G., Palanques, A., 1996. Data report: textural and mineral composition of Cenozoic sedimentary facies off the western Iberian Peninsula, Sites 897, 898, 899 and 900. In: Whitmarsh, R.B., Sawyer, D.S., Klaus, A., Masson, D.G. (Eds.), Proceedings of Ocean Drilling Program, Scientific Results, 149, College Station, TX 149, 741-754.

Álvarez-Salgado, X.A., Figueiras, F.G., Pérez, F.F., Groom, S., Nogueira, E., Borges, A.V., Chou, L., Castro, C.G., Moncoiffe, G., Ríos, A.F., Miller, A.E.J., Frankignoulle, M., Savidge, G., Wollast, R., 2003. The Portugal coastal counter current off NW Spain: new insights on its biogeochemical variability. Progress in Oceanography, 56, 281321.

Alves, T.M, Moita, C., Sandnes, F., Cunha, T., Monteiro, J.H., Pinheiro, L.M., 2006. Mesozoic-Cenozoic evolution of North Atlantic continental-slope basins: the Peniche 
Downloaded from http://sp.lyellcollection.org/ at Consejo Superior De Investigaciones Cientificas (CSIC) on March 6, 2020

basin, western Iberian margin. American Association of Petroleum Geologists Bulletin, 90(1), 31-60.

Alves, T.M., Gawthorpe, R.L., Hunt, D., Monteiro, J.H., 2000. Tertiary evolution of the São Vicente and Setúbal submarine canyons (southwest Portugal): insights from seismic stratigraphy. Cenozoico de Portugal, Ciências da Terra, 207-219.

Alves, T.M., Gawthorpe, R.L., Hunt, D.W., Monteiro, J.H., 2003. Cenozoic tectonosedimentary evolution of the western Iberian margin. Marine Geology, 195, 75-108.

Ambar, I., Armi, L., Bower, A., Ferreira, T., 1999. Some aspects of time variability of the Mediterranean water off south Portugal. Deep-Sea Research, I 46, 1109-1136.

Ambar, I., Fiúza, A., 1994. Some features of the Portugal Current System: A poleward slope undercurrent, an upwelling related southward flow and an autumn-winter poleward coastal surface current. 2nd International Conference on Air-Sea Interaction \& on Meterologoy \& Oceanography of the Coastal Zone, preprints, September 22-27, American Meterological Society, 286-287.

Ambar, I., Howe, M.R., 1979. Observations of the Mediterranean outflow-II. The deep circulation in the vicinity of the Gulf of Cadiz. Deep-Sea Research, 26 A, 555-568.

Ambar, I., Serra, N., Brogueira, M.J., Cabeçadas, G., Abrantes, F., Freitas, P., Gonçalves, C., Gonzales, N., 2002. Physical, chemical and sedimentological aspects of the Mediterranean outflow off Iberia. Deep-Sea Research II, 49, 4163-4177.

Ambar, I., Serra, N., Neves, F., Ferreira, T., 2008. Observations of the Mediterranean Undercurrent and eddies in the Gulf of Cadiz during 2001. Journal of Marine Systems, 71(1-2), 195-220.

Badagola, A., 2008. Evolução morfo-tectónica da plataforma continental do Esporão da Estremadura. Dissertação, Universidade de Lisboa, 171 pp.

Bahr, A. Kaboth, S., Jiménez-Espejo, F.J., Sierro, F.J., Voelker, A.H.L., Lourens, L., Röhl, U., Reichart, G.J., Escutia, C., Hernández-Molina, F.J., Pross, J., Friedrich, O. 2015. Persistent monsoonal forcing of Mediterranean Outflow Water dynamics during the late Pleistocene. Geology, 43: 951-954. doi:10.1130/G37013.1

Bahr, A., Jiménez-Espejo, F.J., Kolasinca, N., Grunert, P., Hernández-Molina, F.J., Röhl, U., Voelker, A., Escutia, C., Stow, D.A.V., Hodell, D., Álvarez-Zarikian, C., 2014, Deciphering bottom current velocity and paleoclimate signals from contourite deposits in the Gulf of Cádiz during the last 140 kyr: An inorganic geochemical approach. Geochemistry Geophysics Geosystems, 15, 3145-3160.

Baringer, M.O., Price, J.F., 1997. Momentum and energy balance of the Mediterranean outflow. Journal of Physical Oceanography, 27(8), 1678-1692.

Baringer, M.O., Price, J.F., 1999. A review of the physical oceanography of the Mediterranean Outflow. Marine Geology155, 63-82.

Brackenridge, R.E., Stow, D.A.V., Hernández Molina, F.J., Jones, C., Mena, A., Alejo, I., Ducassou, E., Llave, E., Ercilla, G., Nombela, M.A., Perez Arlucea, M., Frances, G., 
Downloaded from http://sp.lyellcollection.org/ at Consejo Superior De Investigaciones Cientificas (CSIC) on March 6, 2020

2018. Textural characteristics and facies of sand rich contourite depositional systems. https://doi.org/10.1111/sed.12463

Bender, V.B., Hanebuth, T.J.J., Mena, A., Baumann, K.H., Francés, G., von Dobeneck, T., 2012.Control of sediment supply, palaeoceanography and morphology on late Quaternary sediment dynamics at the Galician continental slope.Geo-Marine Letters, 32, 313-335.

Boillot, G., Malod, J.-A., Dupeuble, P.-A., CYBERE Group, 1987. Mesozoic evolution of Ortegal Spur, North Galicia margin: Comparison with adjacent margins. In: Boillot, G., Winterer, E.L., Meyer, A.W. et al, (Eds.), Proceedings Initial Reports (Pt. A) ODP 103, Texas A\&M University, 107-119.

Borenäs, K.M., Wahlin, A.K., Ambar, I., Serra N., 2002. The Mediterranean outflow splittinga comparison between theoretical models and CANIGO data. Deep-Sea Research II, 49, 4195-4205.

Bormans, M., Garrett, C., 1989. The Effect of Rotation on the Surface Inflow through the Strait of Gibraltar. Journal of Physical Oceanography, 19, 1538-1542.

Botas, J.A., Férnandez, E., Bode, A., Anadón, R., 1989. Water masses off central Cantabrian coast. Scientia Marina, 53, 755-761.

Brackenridge, R., Stow, D.A.V., Hernández-Molina, F.J., 2011. Contourites within a deepwater sequence stratigraphic framework. Geo-Marine Letters, 31, 343-360.

Brackenridge, R.A., Hernández-Molina, F.J., Stow, D.A.V., Llave, E., 2013. A Pliocene mixed contourite-turbidite system offshore the Algarve Margin, Gulf of Cadiz: Seismic response, margin evolution and reservoir implications. Marine and Petroleum Geology, $46,36-50$.

Bryden, H.L. Stommel, H.M., 1984. Limiting processes that determine basic features of the circulation in the Mediterranean Sea. Oceanological Acta, 7, 289-296.

Bryden, H.L., Candela, J., Kinder, T. H., 1994. Exchange through the Strait of Gibraltar. Progress in Oceanography, 33, 201-248.

Buitrago, J., García, C., Cajebread-Brow, J., Jiménez, A., Martínez del Olmo, W., 2001. Contouritas: Un Excelente Almacén Casi Desconocido (Golfo de Cádiz, SO de España). Congreso Técnico Exploración y Producción REPSOL-YPF, Madrid, 24-27 September 2001.

Cakebread-Brown, J., Garcia-Mojonero, C., Bortz, R., Schwarzhans, W., Cortes, L., Olmo, W.M., 2003. Offshore Algarve, Portugal: A prospective extension of the Spanish Gulf of Cadiz Miocene Play. AAPG Intl Conf., Barcelona, Spain. AAPG Bull. 87.

Calvin Campbell, D., Mosher, D.C., 2016. Geophysical evidence for widespread Cenozoic bottom current activity from the continental margin of Nova Scotia, Canada. Marine Geology, Special Issue: The Contourite Log-Book, 378, 237-260. 
Downloaded from http://sp.lyellcollection.org/ at Consejo Superior De Investigaciones Cientificas (CSIC) on March 6, 2020

Canals, M., 1985. Estructura sedimentaria y evolución morfológico del talud y el glacis continentales del Golfo de León: fenómenos de desestabilización de la cobertera sedimentaria plio-cuaternaria. Tesis Doctoral, Univ. Barcelona, 618 pp.

Candela, J., 2001.Mediterranean Water and Global Circulation. In: Sedler, G., Church, J., Gould, J. (Eds.), Ocean Circulation and Climate observing and Modelling the Global Ocean. Academic Press, 419-429.

Caralp, M.H., 1985. Quaternary calcareous benthic Foraminifers, Leg 80. In: de Graciansky, P.C., Poag, C.W., et al.(Eds.), Initial Reports, DSDP, 80(2), Washington (U.S. Govt. Print Office), 725-755.

Cheney, R.E., Doblar, R.A., 1982. Structure and variability of the Alborán Sea frontal system. Journal of Geophysical Research 87(C1), 585-594.

Cherubin, L., Carton, X., Paillet, J., Morel, Y., Serpatte, A., 2000. Instability of the Mediterranean Water undercurrents southwest of Portugal: effects of baroclinicity and topography. Oceanological Acta, 23(5), 551-573.

Collart, T., Verreydt, W., Hernández-Molina, F.J., Llave, E., León, R., Gómez-Ballesteros, M., Pons-Branchu, E., Stewart, H., Van Rooij, D., 2018. Sedimentary processes and cold-water coral mini-mounds at the Ferrol canyon head, NW Iberian margin. Progress in Oceanography. https://doi.org/10.1016/j.pocean.2018.02.027

Collela, A., 1990. Active tidal sand waves at bathyal depths observed from submersible and bathysphere (Messina Strait, southern Italy). 13th IAS Meeting, Pap. Abstracts, 98-99.

Comas, M.C., Maldonado, A., 1988. Late Cenozoic sedimentary facies and processes in the Iberian Abyssal Plain, Site 637, ODP Leg 103. In: Boillot, G., Winterer, E.L., et al. (Eds.), Proceedings ODP, Scientific Results 103, College Station, TX, 635-655.

Copard, K., Colin, C., Frank, N., Jeandel, C., Montero-Serrano, J.-C., Reverdin, G., Ferron, B., 2011. Nd isotopic composition of water masses and dilution of the Mediterranean outflow along the South-West European margin. Geochemistry, Geophysics, Geosystems, 12, Q06020, http://dx.doi.org/10.1029/2011GC003529.

Creaser, A., Hernández-Molina, F.J., Badalini, G., Thompson, P., Walker, R., Soto, M., Conti, B., 2017. A Late Cretaceous mixed (turbidite-contourite) system along the Uruguayan Margin: Sedimentary and palaeoceanographic implications. Marine Geology, 390: 234-253.

Daniault, N., Mazem, J.M., Arhan, M., 1994. Circulation and mixing of Mediterranean Water West of the Iberian Peninsula.Deep-Sea Research, 41, 1685-1714.

Delivet, S., Van Eetvelt, B., Monteys, X., Ribó, M., Van Rooij, D., 2016. Seismic geomorphological reconstructions of Plio-Pleistocene bottom current variability at Goban Spur. Marine Geology, Special Issue: The Contourite Log-Book, 378, 261-275.

Díaz del Río, G., González, N., Marcote, D., 1998. The intermediate Mediterranean water inflow along the northern slope of the Iberian Peninsula. Oceanologica Acta, 21(2), 157-163. 
Downloaded from http://sp.lyellcollection.org/ at Consejo Superior De Investigaciones Cientificas (CSIC) on March 6, 2020

Dickson, R.R., Gould, W.J., Muller, T.J., Maillard, C., 1985. Estimates of the mean circulation in the deep (> $2000 \mathrm{~m}$ ) layer of the eastern North Atlantic. Progress in Oceanography, 14, 103-127.

Duarte, C.S., Viana, A. (2007). Santos Drift System: stratigraphic organization and implications for late Cenozoic palaeocirculation in the Santos Basin, SW Atlantic Ocean. In: Viana, A., Rebesco, M. (Eds.). Economic and Palaeoceanographic Significance of Contourite Deposits Geol. Soc. London Spec. Pub. 276: 171-198.

Enjorlas, J.M., Gouadain, J., Mutti, E., Pizon, J., 1986. New turbiditic model for the Lower Tertiary sands in the South Viking Graben. In: Spencer, A.M. (Ed.), Habitat of Hydrocarbons on the Norwegian Continental Shelf. Norwegian Petroleum Society, Oslo, 171-178.

Ercilla, E., Vilas, F., 2008. Geological characterization of the Galicia Bank Region (Atlantic Ocean, NW Iberia): The marine geology community's response to the Prestige disaster. Marine Geology, 249, 1-6.

Ercilla, G., Baraza, J., Alonso, B., Estrada, F., Casas, D., Farrán, M., 2002. The Ceuta Drift, Alboran Sea (southwestern Mediterranean). In: Stow, D.A.V., Pudsey, C.J., Howe, J.A., Faugères, J.C., Viana, A.R. (Eds.), Deep-Water Contourite Systems: Modern Drifts and Ancient Series, Seismic and Sedimentary Characteristics. Geological Society of London, Memoirs 22, 155-170.

Ercilla, G., Córdoba, D., Gallart, J., Gracia, E., Muñoz, J.A., Somoza, L., Vázquez, J.T., Vilas, F., Prestige group, 2006. Geological characterization of the Prestige sinking area. Marine Pollution Bulletin 53, 208-219.

Ercilla, G., García-Gil, S., Estrada, F., Gràcia, E., Vizcaino, A., Vázquez, T., Díaz, S., Vilas, F., Casas, D., Alonso, B., Dañobeitia, J., Farran, M., 2008a. High resolution seismic stratigraphy of the Galicia Bank Region and neighbouring abyssal plains (NW Iberian continental margin). Marine Geology, 249, 108-127.

Ercilla, G., Casas, D., Estrada, F., Vázquez, T., Iglesias, J., García, M., Gómez, M., Acosta, J., Gallart, J., Maestro-González, A., Marconi Team, 2008b. Morphosedimentary features and recent depositional architectural model of the Cantabrian continental margin. Marine Geology, 247(1-2), 61-83.

Ercilla, G., Casas D., Somoza, L., Vázquez, J.T., Iglesias, J., García-Gil, S., Medialdea, T., León, R., Estrada, F., ERGAP Project and Cruise Teams, 2009. Cartografiando la dinámica sedimentaria de la región del Banco de Galicia. Nuevas Contribuciones al Margen Ibérico. 6th Symposium on the Atlantic Iberian Margin (MIA 09), Abstract volumen, 201-204.

Ercilla, G., Casas, D., Vázquez, J.T., Iglesias, J., Somoza, L., Juan, C., Medialdea, T., León, R., Estrada, F., García-Gil, S., Farran, M., Bohoyo, F., García, M., Maestro, A., ERGAP Project and Cruise Teams, 2011. Imaging the recent sediment dynamics of the Galicia Bank region (Atlantic, NW Iberian Peninsula). Marine Geophysical Researches, 32(1-2), 99-126. 
Downloaded from http://sp.lyellcollection.org/ at Consejo Superior De Investigaciones Cientificas (CSIC) on March 6, 2020

Ercilla, G., Juan, C., Hernández-Molina, F.J., Bruno, M., Estrada, F., Alonso, B., Casas, D., Farran, M., Llave, E., García, M., Vázquez, J.T., D’Acremont, E., Gorini, C., Palomino, D., Valencia, J., El Moumni, B., Ammar, A., 2016. The footprint of the water masses in the uneven development of turbidite systems in the Alboran Sea. Marine Geology, Special Issue: The Contourite Log-Book, 378, 157-170.

Esteras, M., Izquierdo, J., Sandoval, N.G., Mamad, A., 2000. Evolución morfológica y estratigráfica plio-cuaternaria del Umbral de Camarinal (Estrecho de Gibraltar) basada en sondeos marinos. Revista de la Sociedad Geológica de España, 13(3-4), 539-550.

Expedition 339 Scientists, 2012. Mediterranean outflow: environmental significance of the Mediterranean Outflow Water and its global implications. IODP Preliminary Report, 339. doi:10.2204/iodp.pr.339.2012.

Fabres, J., Calafat, A., Sanchez-Vidal, A., Canals, M., Heussner, S., 2002. Composition and spatio-temporal variability of particle fluxes in the Western Alboran Gyre, Mediterranean Sea. Journal of Marine Systems, 33-34, 431-456.

Faugères, J.-C., Stow, D.A.V., 1993. Bottom-current-controlled sedimentation: a synthesis of the contourite problem. Sedimentary Geology, 82, 287-297.

Faugères, J.-C., Stow, D.A.V., 2008. Sediment drift drifts: nature, evolution and controls. In: Rebesco, M., Carmerlenghi, A. (Eds.), Sediment drifts, Developments in Sedimentology, Elsevier, 60, 250-288.

Faugères, J. C., Gonthier, E., Stow, D.A.V., 1984. Contourite drift molded by deep Mediterranean outflow. Geology, 12, 296-300.

Faugères, J. C., Frappa, M., Gonthier, E., De Resseguier, A., Stow, D.A.V., 1985a. Modelé et facies de type contourite a la surface d'une ride sédimentaire édifiée par des courants issus de la veine d'eau méditerranéenne (ride du Faro, Golle de Cadix). Bull. Soc. Géol. France I (1), 35-47.

Faugères, J. C., Cremer, M., Monteiro, H., Gaspar, L., 1985b. Essai de reconstitution des processus d'edification de la ride sedimentaire de Faro (Marge Sud-Portugaise). Bull. Inst. Géol. Bassin d’Aquitaine, 37, 229-258.

Faugères, J.C., Stow, D.A.V., Imbert, P., Viana, A., 1999. Seismic features diagnostic of contourite drifts. Marine Geology, 162, 1-38.

Fiúza, A.F.G., 1984. Hidrologia e dinamica das aguas costeiras de Portugal'. These Doctoral Science, Univiversity. Lisbonne, Portugal 294 pp.

Fiúza, A.F.G., Halpern, D., 1982. Hydrographic observations of the Canary Current between $21 \mathrm{jN}$ and $25.5 \mathrm{jN}$ in March/April 1974. Rapport et Procès-verbaux of Réunions. Conseil International de l'Exploration de la Mer, 180, 58-64.

Fiúza, A.F.G., Hamann, M., Ambar, I., Díaz del Río, G.D., González, N., Cabanas, J.M., 1998. Water masses and their circulation off western Iberia during May 1993. DeepSea Research, 45, 1127-1160. 
Downloaded from http://sp.lyellcollection.org/ at Consejo Superior De Investigaciones Cientificas (CSIC) on March 6, 2020

García, M., 2002. Caracterización Morfológica del Sistema de Canales y Valles Submarinos del Talud Medio del Golfo de Cádiz (SO de la Península Ibérica): Implicaciones Oceanográficas. Tesis de Licenciatura, Facultad de Ciencias del Mar, University of Cádiz, $114 \mathrm{pp}$.

García, M., Hernández-Molina, F.J., Llave, E., Stow, D.A.V., León, R., Fernández-Puga, M.C., Díaz del Río, V., Somoza, L., 2009. Contourite erosive features caused by the Mediterranean Outflow Water in the Gulf of Cadiz: Quaternary tectonic and oceanographic implications. Marine Geology, 257, 24-40.

García, M., Hernández-Molina, F.J., Alonso, B., Vázquez, J.T., Ercilla, G., Llave, E., Casas, D., 2016. Erosive sub-circular depressions on the Guadalquivir Bank (Gulf of Cadiz): Interaction between bottom current, mass-wasting and tectonic processes. Marine Geology, Special Issue: The Contourite Log-Book, 378, 5-19.

García-Lafuente, J., Sánchez Garrido, J.C., Díaz del Río, G., Criado Aldeanueva, F., Marcote, D., Sánchez Román, A., 2008. Low-frequency variability of the Mediterranean undercurrent off Galicia, northwestern Iberian Peninsula. In: Gómez Gesteira, M.G., de Castro, M., Rosón, G. et al. (Eds.), Journal of Marine System, 74(14), 351-363.

García-Mojonero, C., Martinez del Olmo, W., 2001. 2001. One sea level fall and four different gas plays: the Gulf of Cadiz Basin, SW Spain. In: Fillon, R.H., Rosen, N.C (Eds.), Program and Abstracts, GCSSEMP Foundation 21st Annual Bob E Perkins Research Conference, 357-367.

García-Soto, C., Pingree, R.D., Valdeés, L., 2002. Navidad development in the southern Bay of Biscay: climate change and swoddy structure from remote sensing and in situ measurements. Journal of Geophysical Research 107, C8.

Gardner, J.V., Kidd, R.B., 1983. Sedimentary processes on the Iberian continental margin viewed by long-range side-scan sonar. 1: Gulf of Cadiz. Oceanologica Acta, 6(3), 245254.

Gardner, J.V., Kidd, R.B., 1987. Sedimentary processes on the northwestern Iberian continental margin viewed by long-range side-scan sonar and seismic data. Journal of Sedimentary Petrology, 57, 397-407.

Gascard, J.C., Richez, C., 1985. Water masses and circulation in the Western Alboran Sea and in the Straits of Gibraltar. Progress in Oceanography, 15,157-216,

GEBCO, 2003. One minute global bathymetric grid from The General Bathymetric Chart of the Oceans. http://www.ngdc.noaa.gov/mgg/gebco/.

Gonthier, E.G., Faugères, J.C., Stow, D.A.V., 1984. Contourite facies of the Faro Drift, Gulf of Cadiz. In: Stow, D.A.V., Piper, D.J.W. (Eds.), Fine-Grained Sediments, Deep-Water Processes and Facies. Geological Society Special Publication, 15, 275-292.

González-Pola, C. 2006. Variabilidad climática en la región sureste del Golfo de Vizcaya. Tesis de Maestría, Universidad de Oviedo, Oviedo, 196 pp. 
Downloaded from http://sp.lyellcollection.org/ at Consejo Superior De Investigaciones Cientificas (CSIC) on March 6, 2020

Gruetzner, J., Uenzelmann-Neben, G., 2016. Contourite drifts as indicators of Cenozoic bottom water intensity in the eastern Agulhas Ridge area, South Atlantic. Marine Geology, Special Issue: The Contourite Log-Book, 378, 350-360.

Gründlingh, M., 1981. On the observation of a solitary event in the Mediterranean Outflow west of Gibraltar. Meteor- Forschungsergebnisse, A/B (23), 15-46.

Habgood, E.L., 2002. Alongslope and downslope sediment transport processes in the Gulf of Cádiz. PhD Thesis, University of Soutampton, 237 pp.

Habgood, E.L., Kenyon, N.H., Masson, D.G., Akhmetzhanov, A., Weaver, P.P.E., Gardner, J., Mulder, T., 2003. Deep-water sediment wave fields, bottom current sand channels and gravity flow channel-lobe systems: Gulf of Cádiz, NE Atlantic. Sedimentology, 50, 483-510.

Hanebuth, T.J.J., Zhang, W., Hofmann, A.L., Loewemark, L.A., Schwenk, T., 2015. Oceanic density fronts steering bottom-current induced sedimentation deduced from a $50 \mathrm{ka}$ contourite drift record and numerical modelling (off NW Spain). Quaternary Science Reviews, 112, 207-225.

Hanquiez, V., 2006. Processus sédimentaires et activité de la Veine d'Eau Méditerranéenne au cours du Quaternaire terminal dans le Golfe de Cadix. Thèse, Université Bordeaux 1 , Talence.

Hanquiez, V., Mulder, T., Lecroart, P., Gonthier, E., Marchès, E., Voisset, M., 2007. High resolution seafloor images in the Gulf of Cadiz, Iberian margin. Marine Geology, 28, 42-59.

Hay, W.W., 2009. Cretaceous oceans and ocean modeling. SEPM Special Publication No. 91, SEPM (Society for Sedimentary Geology), 243-271.

Haynes, R., Barton, E.D., 1990. A poleward flow along the Atlantic coast of the Iberian Peninsula. Journal of Geophysical Research, 95, 11425-11441.

Hernández-Molina, F.J., Somoza, L., Lobo, F., 2002. Quaternary stratigraphic stacking patterns on the continental shelves of the southern Iberian Peninsula: Their relationship with global climate and palaeoceanographic changes. Quaternary International, 92(1), 5-23.

Hernández-Molina, F.J., Llave, E., Somoza, L., Fernández-Puga, M.C., Maestro, A., León, R., Barnolas, A., Medialdea, T., García, M., Vázquez, J.T., Díaz del Río, V., Fernández-Salas, L.M., Lobo, F., Alveirinho Dias, J.M., Rodero, J., Gardner, J., 2003. Looking for clues to paleoceanographic imprints: a diagnosis of the gulf of Cadiz contourite depositional systems. Geology, 31(1), 19-22.

Hernández-Molina, F.J., Llave, E., Stow, D.A.V., García, M., Somoza, L., Vázquez, J.T., Lobo, F.J., Maestro, A., Díaz del Río, V., León, R., Medialdea, T., Gardner, J., 2006. The contourite depositional system of the Gulf of Cádiz: A sedimentary model related to the bottom current activity of the Mediterranean outflow water and its interaction with the continental margin. Deep Sea Research II, 53, 1420-1463. 
Downloaded from http://sp.lyellcollection.org/ at Consejo Superior De Investigaciones Cientificas (CSIC) on March 6, 2020

Hernández-Molina, F.J., Llave, E., Stow, D.A.V., 2008a. Continental Slopes Contourites. In: Rebesco, M., Camerlenghi, A. (Eds.), Contourites. Developments in Sedimentology 60, Elsevier, 379-408.

Hernández-Molina, F.J., Maldonado, A., Stow, D.A.V., 2008b. Sediment drift of Abyssal plains and oceanic basins. In: Rebesco, M., Camerlenghi, A. (Eds.), Contourites. Developments in Sedimentology 60, Elsevier, 347-378.

Hernández-Molina, F.J., Llave, E., Fontan, A., Brackenridge, R.E., Stow, D.A.V., Ercilla, G., Medialdea, T., García, M., Sandoval, N., Preu, B., Arlucea, M.P., Nombela, M.A., Alejo, I., Francés, G., Mena, A., Casas, D., Somoza, L., León, R., Vázquez, J.T., Juan, C., Van Rooij, D., Matias, H., Bruno, M., Serra, N. and Contouriber Team, 2012. First evidence of a main channel generated by the Mediterranean Outflow Water after its exit from the Gibraltar Strait. VIII Congreso Geológico de España, Oviedo, Geotemas 13.

Hernández-Molina, F.J., Serra, N., Stow, D.A.V., Ercilla, G., Llave, E., Van Rooij, D., 2011. Along-slope oceanographic processes and sedimentary products around Iberia. In: Hernández-Molina, F.J., Stow, D.A.V., Llave, E. et al., (Eds.), Deep Water Circulation: processes and products. Geo-Marine Letters, 31(5-6), 315-341.

Hernández-Molina, F.J., Stow, D.A.V., Alvarez-Zarikian, C., Expedition IODP 339 Scientists, 2013. IODP Expedition 339 in the Gulf of Cadiz and off West Iberia: decoding the environmental significance of the Mediterranean Outflow Water and its global influence. Scientific Drilling, 16, 1-11.

Hernández-Molina, F.J., Llave, E., Preu, B., Ercilla, G., Fontan, A., Bruno, M., Serra, N., Gomiz, J.J., Brackenridge, R.E., Sierro, F.J., Stow, D.A.V., García, M., Juan, C., Sandoval, N., Arnaiz, A., 2014a. Contourite processes associated with the Mediterranean Outflow Water after its exit from the Strait of Gibraltar: Global and conceptual implications. Geology, 42(3), 227-230.

Hernández-Molina, F.J., Stow, D.A.V., Alvarez-Zarikian, C., Expedition IODP 339 Scientists, 2014b. Onset of Mediterranean outflow into the North Atlantic. Science, 344, 12441249.

Hernández-Molina, F.J., Wåhlin, A., Bruno, M., Ercilla, G., Llave, E., Serra, N., Roson, G., Puig, P., Rebesco, M., Van Rooij, D., Roque, C., González-Pola, C., Sánchez, F., Gómez, M., Preu, B., Schwenk, T., Hanebuth, T.J.J., Sánchez-Leal, R.F., GarcíaLafuente, J., Brackenridge, R.E., Juan, C., Stow, D.A.V., Sánchez-González, J.M., 2016a. Oceanographic processes and products around the lberian margin: a new multidisciplinary approach. Marine Geology, Special Issue: The Contourite Log-Book, 378, 127-156.

Hernández-Molina, F.J., Sierro, F.J., Llave, E., Roque, C., Williams, T., Lofi, J., Van der Schee, M., Arnaiz, A., Ledesma, S., Rosales, C., Rodríguez-Tovar, F.J., PardoIgúzquiza, E., Brackenridge, R., 2016b. Evolution of the gulf of Cadiz margin and southwest Portugal contourite depositional system: Tectonic, sedimentary and paleoceanographic implications from IODP expedition 339. Marine Geology, 377, 7-39. 
Downloaded from http://sp.lyellcollection.org/ at Consejo Superior De Investigaciones Cientificas (CSIC) on March 6, 2020

Hernández-Molina, F.J., Soto, M., Piola, A.R., Tomasini, J., Preu, B., Thompson, P., Badalini, G., Creaser, A., Violante, R.A., Morales, E., Paterlini, M., De Santa Ana, H., 2016c. A contourite depositional system along the Uruguayan continental margin: Sedimentary, oceanographic and paleoceanographic implications. Marine Geology, Special Issue: The Contourite Log-Book, 378, 333-349.

Howe, J.A., Stoker, M.S., Stow, D.A.V., 1994. Late Cenozoic sediment drift complex, northeast Rockall trough, North Atlantic. Paleoceanography, 9, 989-999.

Huneke, N.V., Stow, D., 2008. Identification of ancient contourites: problems and palaeoceanographic significance. In: Rebesco, M. and Camerlenghi, A., (Eds.), Contourites. Amsterdam, the Netherlands: Elsevier, 323-344.

Iglesias, J., 2009. Sedimentation on the Cantabrian Continental Margin from Late Oligocene to Quaternary. Ph D. Universidad de Vigo, $185 \mathrm{pp}$.

lorga, M., Lozier, M.S., 1999. Signatures of the Mediterranean outflow from a North Atlantic climatology. 1. Salinity and density fields. Journal of Geophysical Research, 194, 25985-26029.

Jane, G., Llave, E., Hernández-Molina, F.J., Maestro, A., Ercilla, G., López-Martínez, J., De Andrés, J.R., González-Aller, D., Catalán-Morollón, M., 2012. Contourite features along the Northweastern Iberian continental margin and abyssal plain: the local influence of regional water masses in a down-slope dominate margin. 34 International Geological Congress, Volume of Abstracts, Brisbane (Australia).

Juan, C., Ercilla, G., Estrada, F., Casas, D., Alonso, B., García, M., Farran, M., Palomino, D., Vázquez, J.T., Llave, E., Hernández-Molina, F.J., Medialdea, T., Gorini, C., D’Acremont, E., El Moumni, B., Gensous, B., Tesson, M., Maldonado, A., Ammar, A., Contouriber and Montera Teams, 2012. Contourite sedimentation in the Alboran Sea: Plio-Quaternary evolution. Geo-Temas, 13, 1817-1820.

Juan, C., Ercilla, G., Hernández-Molina, F.J., Estrada, F., Alonso, B., Casas, D., García, M., Farran, M., Llave, E., Palomino, D., Vázquez, J.T., Medialdea, T., Gorini, C., D'Acremont, E., El Moumni, B., Ammar, A., Contouriber, Montera and Action Marges Teams, 2013. Paleo-circulation patterns in the Alboran Sea inferred from the contourite register since the Messinian. 30th International Association of Sedimentologist, Meeting of Sedimentology, September, t3-s4.

Juan, C., Ercilla, G., Hernández-Molina, F. J., Estrada, F., Alonso, B., Casas, D., García, M., Farran, M., Llave, E., Palomino, D., Vázquez, J.T., Medialdea, T., Gorini, C., D'Acremont, E., El Moumni, B., Ammar, A., 2014. (Paleo) circulation models in the Alboran seas during the Pliocene and Quaternary. In: D. Van Rooij and A. Rüggeberg. 2nd Deep-Water Circulation Congress, The Contourite Log-Book. Ghent, Vilzz Special Publication, 69, 91-92.

Juan, C., Ercilla, G., Hernández-Molina, F.J., Estrada, F., Alonso, B., Casas, D., García, M., Farran, M., Llave, E., Palomino, D., Vázquez, J.T., Medialdea, T., Gorini, C., D'Acremont, E., El Moumni, B., Ammar, A., Contouriber, Montera and Action Marges Teams, 2016. Current-controlled sedimentation in the Alboran Sea during the Pliocene 
Downloaded from http://sp.lyellcollection.org/ at Consejo Superior De Investigaciones Cientificas (CSIC) on March 6, 2020

and Quaternay. Marine Geology, Special Issue: The Contourite Log-Book, 378, 292311.

Kelling, G., Stanley, D.J., 1972. Sedimentary evidence of bottom current activity, Strait of Gibraltar region. Marine Geology, 13, M51-M60.

Kenyon, N.H., Belderson, R.H., 1973. Bed forms of the Mediterranean undercurrent observed with side-scan sonar. Sedimentary Geology, 9(2), 77-99.

Kuijpers, A., Nielsen, T., 2016. Near-bottom current speed maxima in North Atlantic contourite environments inferred from current-induced bedforms and other seabed evidence. Marine Geology, Special Issue: The Contourite Log-Book, 378, 230-236.

Lacombe, H., Lizeray, J.C., 1959. Sur le régime des courants dans le Détroit de Gibraltar. Comptes Rendus de l'Académie des Sciences de Paris, 248, 2502-2504.

Le Floch, J., 1969. Evolution rapide de regimes de circulation non permanents des couches d'eaux super"cielles dans le secteur sud-est du Golfe de Gascogne. Cahiers Oceanographiques XXII, 269-276.

Lebreiro, S.M., Antón, L., Reguera, M.I., Fernández, M., Conde, E., Barrado, A.I., Yllera, A., 2015. Zooming into the Mediterranean outflow fossil moat during the 1.2-1.8 million years period (Early-Pleistocene) - An approach by radiogenic and stable isotopes. Global and Planetary Change, 135, 104-118.

Llave, E., 2003. Análisis morfosedimentario y estratigráfico de los depósitos contorníticos del Golfo de Cádiz: Implicaciones paleoceanográficas. PhD Thesis, Facultad de Ciencias del Mar, University of Cádiz, 343 pp.

Llave, E., Hernández-Molina, F.J., Somoza, L., Díaz-del-Río, V., Stow, D.A.V., Maestro, A., Alveirinho Dias, J.M., 2001. Seismic stacking pattern of the Faro-Albufeira contourite system (Gulf of Cadiz): A Quaternary record of paleoceanographic and tectonic influences. Marine Geophysical Researches, 22, 487-508.

Llave, E., Hernández-Molina, F.J., Somoza, L., Stow, D.A.V., Díaz-del-Río, V., 2005. The Contourite Depositional System in the Gulf of Cadiz: a unique Quaternary example of different drifts with reservoir potential characteristics. In: Wenceslao, M.O. (Ed.), 5 Aniversario de la Asociación de Geólogos y Geofísicos Españoles del Petróleo, AGCEP \& REPSOL-YPF, 53-74.

Llave, E., Schönfeld, J., Hernández-Molina, F.J., Mulder, T., Somoza, L., Díaz del Río, V., Sánchez-Almazo, I., 2006. High-resolution stratigraphy of the Mediterranean outflow contourite system in the Gulf of Cadiz during the late Pleistocene: The impact of Heinrich events. Marine Geology, 227, 241-262.

Llave, E., Hernández-Molina, F. J., Somoza, L., Stow, D., Díaz del Río, V., 2007. Quaternary evolution of the Contourite Depositional System in the Gulf of Cadiz. In: Viana, A., Rebesco, M. (Eds.), Economic and Paleoceanographic Importance of Contourites. Geological Society of London, Special Publication, 276, 49-79. 
Downloaded from http://sp.lyellcollection.org/ at Consejo Superior De Investigaciones Cientificas (CSIC) on March 6, 2020

Llave, E., Matias, H., Hernández-Molina, F.J., Ercilla, G., Stow, D.A.V., Medialdea, T., 2011. Pliocene and Quaternary seismic stacking pattern and distribution of contourites in the Algarve margin (Northern Gulf of Cadiz, Spain). Geo-Mar Letters, 31(5-6), 377-390.

Llave, E., Jané, G., Hernández-Molina, F.J., Maestro, A., Ercilla, G., Alejo, I., Nombela, M.A., Francés, G., Pérez-Arlucea, M., Mena, A., López-Martínez, J., De-Andrés, J.R., González-Aller, D., Catalán-Morollón, M., 2013. Sandy contourites along the continental margin of the northwestern Iberian Peninsula. 30th International Association of Sedimentologist, Manchester (UK), Abstract Volume, T3S4.

Llave, E., Hernández-Molina, F.J., Ercilla, G., Roque, C., Van Rooij, D., García, M., Juan, C., Mena, A., Brackenridge, R.E., Jané, G., Stow, D.A.V., Gómez-Ballesteros, M., 2015. Bottom current processes along the Iberian continental margin. In: Maestro, A., Ercilla, G., Hernández-Molina, F.J., (Eds.), Procesos geológicos en el Margen Continental Ibérico, Boletín Geológico y Minero, Volumen Especial, 126(2-3), 219-256.

Llave, E., Jané, G., Maestro, A., López-Martínez, J., Hernández-Molina, F.J., Mink, S., 2018. Geomorphological and sedimentary processes of the glacially influenced northwestern Iberian margin and abyssal plains. Geomorphology. https://doi.org/10.1016/j.geomorph.2018.03.022

Lofi, J., Voelker, A., Ducassou, E., Hernández-Molina, F.J., Sierro, F.J., Bahr, A., Galvani, A., Lourens, L., Pardo-Igúzquiza, E., Pezard, P., Rodríguez-Tovar, F.J., Williams, T., 2016. Quaternary chronostratigraphic framework and sedimentary processes for the Gulf of Cadiz and Portuguese Contourite Depositional Systems derived from Natural Gamma Ray records. Marine Geology, 377, 40-57.

Louarn, E., Morin, P., 2011. Antarctic Intermediate Water influence on Mediterranean Sea Water outflow. Deep Sea Research Part I: Oceanographic Research Papers, 58, 932942.

Lozier, S., Sidlinger, L., 2009. On the source of Mediterranean Overflow Water property changes. Journal of Physical Oceanography, 39, 1800-1819.

Lüdmann, T., Wiggershaus, S., Betzler, C., Hübscher, C., 2012. Southwest Mallorca Island: A cool-water carbonate margin dominated by drift deposition associated with giant mass wasting. Marine Geology, 289, 1-15.

Madelain, F., 1970. Influence de la topographie du fond sur l'ecoulement méditerranéen entre le Detroit de Gibraltar et le Cap Saint-Vincent. Cahiers Océanographiques, 22, 43-61.

Maestro, A., López-Martínez, J., Llave, E., Bohoyo, F., Acosta, J., Hernández-Molina, F.J., Muñoz, A., Jané, A., 2013. Morphology of the Iberian continental margin. Geomorphology, 196, 13-35.

Maldonado, A., 1979. Upper Cretaceous and Cenozoic depositional processes and facies in the distal North Atlantic continental margin off Portugal, DSDP Site 398. In Sibuet, J.C., Ryan, W.B.F., et al., Initial Reports. DSDP, 47 (Pt. 2): Washington, DC (U.S. Govt. Printing Office), 373-402. 
Downloaded from http://sp.lyellcollection.org/ at Consejo Superior De Investigaciones Cientificas (CSIC) on March 6, 2020

Maldonado, A., Somoza, L., Pallarés, L., 1999. The Betic orogen and the Iberian-African boundary in the Gulf of Cádiz: geological evolution (central North Atlantic). Marine Geology, 155(1-2), 9-43.

Marchès, E., Mulder, T., Cremer, M., Bonnel, C., Hanquiez, V., Gonthier, E., Lecroart, P., 2007. Contourite drift construction influenced by capture of Mediterranean Outflow Water deep-sea current by the Portimão submarine canyon (Gulf of Cadiz, South Portugal). Marine Geology, 242, 247-260.

Marchès, E., Mulder, T., Gonthier, E., Cremer, M., Hanquiez, V., Garlan, T., Lecroart, P., 2010. Perched lobe formation in the Gulf of Cadiz: Interactions between gravity processes and contour currents (Algarve Margin, Southern Portugal). Sedimentary Geology, 229(3), 81-94.

Martins, C.S., Hamann, M., Fuiza, A.F.G., 2002: Surface circulation in the eastern North Atlantic from drifters and altimetry. Journal of Geophysical Research, 107, 3217.

Masson, D.G., Wynn, R.B., Bett, B.J., 2004. Sedimentary environment of the FaeroeShetland Channel and Faeroe Bank channels, NE Atlantic, and the use of bedforms as indicators of bottom current velocity in the deep ocean. Sedimentology, 51, 1-35.

Mauffret, A., 1979. Etude géodynamique de la marge des Illes Baléares. Mémoires de la Société Géologique de France, LVI(132), 1-96.

Mazé, J.P., Arhan, M., Mercier, H., 1997. Volume budget of the eastern boundary layer off the Iberian Peninsula. Deep Sea Research, 44, 1543-1574.

McCartney, M.S., 1992. Recirculating components to the deep boundary current of the northern North Atlantic. Progress in Oceanography, 29, 283-383.

McCartney, M.S., Talley, L.D., 1982. The Subpolar Mode Water of the North Atlantic Ocean. Journal of Physical Oceanography, 12, 1169-1188.

McCave, I.N., Hall, I.R., Antia, A.N., Chou, L. Dehairs, F., Lampitt, R.S., Thomsen, L., Van Weering, T.C.E., Wollast, R., 2001. Distribution, composition and flux of particulate material over the European margin at $47^{\circ}-50^{\circ} \mathrm{N}$. Deep Sea Research I, 48, 31073139.

Melières, F., Nesteroff, W.D., Lancelot, Y., 1970. Etude photographique des fonds du Golfe de Cádiz. Cahiers Oceanographiques, 22, 63-72.

Milkert, D., Alonso, B., Liu, L., Zhao, X., Comas, M., de Kaenel, E., 1996. Sedimentary facies and depositional history of the Iberia abyssal plain, Proceedings of the Ocean Drilling Program, Scientific Results, 149, 685-704.

Millot, C., 1999. Circulation in the Western Mediterranean Sea. Journal of Marine Systems, 20, 423-442.

Millot, C., 2009. Another description of the Mediterranean outflow. Progress in Oceanography, 82(2), 101-124. 
Downloaded from http://sp.lyellcollection.org/ at Consejo Superior De Investigaciones Cientificas (CSIC) on March 6, 2020

Millot, C., 2014. Heterogeneities of in- and out-flows in the Mediterranean Sea. Progress in Oceanography, 120, 254-278.

Millot, C., J. Candela, J. L. Fuda, Tber, Y., 2006. Large warming and salinification of the Mediterranean outflow due to changes in its composition. Deep Sea Research I, 53, 656-666.

Mougenot, D., 1988. Géologie de la Marge Portuguise. These de doctorat d'État, Mem. Sci. Terre Univ. Curie, Paris VI, 257 pp.

Mougenot, D., 1989. Geologia da Margem Portuguesa. Instituto Hidrográfico, 259 pp.

Mulder, T., Lecroart, P., Voisset, M., Le Drezen, E., Gonthier, E., Hanquiez, V., Faugères, J.C., Gervais, A., Kenyon, N.H., Schönfeld, J., Hernández-Molina, F.J., Habgood, E., Poirier, D., Llave-Barranco, E., Estrada, F., Voelker, A., Gorini, C., Freitas, P., Lobo Sanchez, F., Fuchey, Y., Fernandez, L.M., Morel, J., 2002. Past deep-ocean circulation and the palaeoclimate record-Gulf of Cadiz. EOS, Transations, American Geophysical Union, 83(43), 481-488.

Mulder, T., Voisset, M., Lecroart, P., Le Drezen, E., Gonthier, E., Hanquiez, V., Faugères, J.C., Habgood, E., Hernández-Molina, F.J., Estrada, F., Llave, E., Poirier, D., Gorini, C., Fuchey, Y., Voelker, A., Freitas, P., Lobo Sanchez, F., Fernandez, L.M., Morel, J., 2003. The Gulf of Cadiz: an unstable giant contouritic levee. Geo-Mar Letters, 23(1), 718.

Mulder, T., Lecroart, P., Hanquiez, V., Marchès, E., Gonthier, E., Guedes, J.C., Thiébot, E., Jaaidi, B., Kenyon, N., Voisset, M., Perez, C., Sayago, M., Fuchey, Y., Bujan, S., 2006. The western part of the Gulf of Cadiz: contour currentsand turbidity currents interactions. Geo-Marine Letters, 26, 31-41.

Mulder, T., Faugères, J.C., Gonthier, E., 2008. Mixed turbidite-contourite systems. In: Rebesco M, Camerlenghi A (Eds.) Contourites. Developments in sedimentology, 60. Elsevier, Amsterdam, 435-456.

Mulder, T., Hassan, R., Ducassou, E., Zaragosi, S., Gonthier, E., Hanquiez, V., Marchès, E., Toucanne, S., 2013. Contourites in the Gulf of Cadiz: a cautionary note on potentially ambiguous indicators of bottom current velocity. Geo-marine Letters, 33(5), 357-367.

Mutti, E., 1992. Ancient deep-water siliciclastic systems: what do we really know? B.S.R.G. Workshop on Deep-water Clastics: Dynamics of Modern and Ancient Systems, Oxford, Programme and Abstract, 2 pp.

Mutti, E., Carminatti, M., 2012. Deep-water sands of the Brazilian offshore basins. American Association of Petroleum Geologists International Conference and Exhibition, Milan, Italy, October 23-26, 2011, Search and Discovery Article 30219, 1-42.

Mutti, E., Barros, M., Possato, S., Rumenos, L., 1980. Deep-sea fan Turbidite Sediments Winnowed by Bottom-Currents in the Eocene of the Campos Basin, Brazilian Offshore. 1st IAS Eur. Meet. Abstr, p. 114. 
Downloaded from http://sp.lyellcollection.org/ at Consejo Superior De Investigaciones Cientificas (CSIC) on March 6, 2020

Nelson, C.H., Baraza, J., Maldonado, A., 1993. Mediterranean undercurrent sandy contourites, Gulf of Cadiz. Spain. Sedimentary Geology, 82, 103-131.

Nelson, C.H., Baraza, J., Rodero, J., Maldonado, A., Escutia, C., Barber, Jr. J.H., 1999. Influence of the Atlantic inflow and Mediterranean outflow currents on Late Pleistocene and Holocene sedimentary facies of Gulf of Cadiz continental margin. Marine Geology, $155,99-129$.

Neves, M.C., Terrinha, P., Afilhado, A., Moulin, M., Matias, L., Rosas, F., 2009. Response of a multi-domain continental margin to compression: Study from seismic reflectionrefraction and numerical modelling in the Tagus Abyssal Plain. Tectonophysics, 468, 113-130.

Nielsen, T., Kuijpers, A., Knutz, P., 2008. Seismic expression of contourite depositional systems. In: Rebesco M, Camerlenghi A (Eds.) Contourites. Developments in sedimentology, 60. Elsevier, Amsterdam, 301-322.

Ochoa, J., Bray, N.A., 1991. Water mass exchange in the Gulf of Cadiz. Deep-Sea Research, 38(1), S465-S503.

Paillet, J., Arhan, M., MacCartney, M.S., 1998. Spreading of Labrador Sea Water in the eastern North Atlantic. Journal of Geophysical Research, 103(C5), 10223-10239.

Paillet, J., Mercier, H., 1997. An inverse model of the eastern North Atlantic general circulation and thermocline ventilation. Deep-Sea Research, 44, 1293-1328.

Palomino, D., Vázquez, J.T., Ercilla, G., Alonso, B., López-González, N., Díaz del Río, V., Fernández-Salas, L.M., 2010. Influence of water masses on the seabed morphology around the Seamounts of the Motril Marginal Shelf (Alboran Sea, Western Mediterranean). Geo-Temas, 11, 131-132.

Palomino, D., Vázquez, J.T., Ercilla, G., Alonso, B., López-González, N., Díaz del Río, V., Fernández-Salas, L.M., 2011. Interaction between seabed morphology and water masses around the seamounts on the Motril Marginal Plateau (Alboran Sea, Western Mediterranean). Geo-Marine Letters, 31, 465-479.

Parrilla, G., Kinder, T.H., 1987. Oceanografía física del mar de Alborán. Boletín Instituto Español de Oceanografía, 4, 133-165.

Peliz, A., J. Dubert, A. Santos, P. Oliveira, Le Cann, B., 2005. Winter upper ocean circulation in the western Iberian Basin-Fronts, eddies and poleward flows: An overview. Deep Sea Research I, 52, 621-646.

Pereira, R., Alves, T., 2011. Margin segmentation prior to continental break-up: A seismicstratigraphic record of multiphased rifting in the North Atlantic (Southwest Iberia). Tectonophysics, 505, 17-34.

Pérez, F.F., A.F. Ríos, B.A. King, Pollard, R.T., 1995. Decadal changes of the O-S relationship of the Eastern North Atlantic Central Water. Deep-Sea Research, 42, 1849-1864. 
Downloaded from http://sp.lyellcollection.org/ at Consejo Superior De Investigaciones Cientificas (CSIC) on March 6, 2020

Pérez, F.F., C.G. Castro, X.A. Álvarez-Salgado, Ríos, A.F., 2001. Coupling between the Iberian basin-scale circulation and the Portugal boundary current system. A chemical study. Deep Sea Research I, 48, 1519-1533.

Periáñez, R., 2006. Modelling surface radioactive spill dispersion in the Alborán Sea. Journal of Environmental Radioactivity, 90(1), 48-67.

Periáñez, R., 2007. Chemical and oil spill rapid response modeling in the Strait of GibraltarAlborán Sea. Ecological Modelling, 207(2-4), 210-222.

Perkins, H., Kinders, T., Violette, P., 1990. The Atlantic inflowing the Western Alboran Sea. Journal of Physical Oceanography, 20, 242-263.

Pickering, K.T., Hiscot, R.N., 2016. Deep Marine Systems. Processes, Deposits, Environments, Tectonics and Sedimentation. AGU \& Wiley, 657 pp.

Pickering, K.T., Hiscot, R.N.,Hein, F.J., 1989. Marine Environments. Clastic Sedimentation and Tectonics. London, Boston, Sydney, Wellington: Unwin Hyman, 416 pp.

Pingree, R.D., Le Cann, B., 1990. Structure, strength and seasonality of the slope currents in the Bay of Biscay region. Journal of the Marine Biological Association of the United Kingdom, 70, 857-885.

Pollard, R., Pu, S., 1985. Structure and circulation of the upper Atlantic Ocean northeast of ther Azores. Progress in Oceanography, 14, 443-462.

Potter, R., Lozier, S., 2004. On the warming and salinifi cation of the Mediterranean outfl ow waters in the North Atlantic. Geophysical Research Letter, 31, L01202.

Rebesco, M., 2005. Contourites. In: Richard, C., Selley, R.C., Cocks, L.R.M., Plimer, I.R. (Eds.), Encyclopedia of Geology, 4, Elsevier, London, 513-527.

Rebesco, M., Camerlenghi, A. (Eds.), 2008. Contourites. Developments in Sedimentology, 60, Elsevier, $663 \mathrm{pp}$.

Rebesco, M., Stow, D.A.V., 2001. Seismic expression of contourites and related deposits: a preface. Marine and Geophysical Research, 22, 303-308.

Rebesco, M., Hernández-Molina, F.J., Van Rooij, D., Wahlin, A., 2014. Contourites and associated sediments controlled by deep-water circulation processes: state of the art and future considerations. Marine Geology, SI: 50th anniversary, 111-154.

Ribó, M., Puig, P., Urgeles, R., Van Rooij, D., Muñoz, A., 2016. Spatio-temporal evolution of sediment waves developed on the Gulf of Valencia margin (NW Mediterranean) during the Plio-Quaternary. Marine Geology, Special Issue: The Contourite Log-Book, 378, 276-291.

Rios, A.F., Pérez, F.F., Fraga, F.F., 1992. Water masses in the upper and middle North Atlantic Ocean east of the Azores. Deep-Sea Research, 39, 645-658. 
Downloaded from http://sp.lyellcollection.org/ at Consejo Superior De Investigaciones Cientificas (CSIC) on March 6, 2020

Robinson, A., Leslie, W., Theocharis, A., Lascaratos, A., 2001. Mediterranean Sea circulation, 1689-1706, in Encyclopedia of Ocean Sciences, Academic Press Ltd., London.

Rogerson, M., Rohling, E.J., Weaver, P.P.E., Murray, J.W., 2005. Glacial to interglacial changes in the settling depth of the Mediterranean Outflow plume. Paleoceanography, 20, PA3007.

Rogerson, M., Rohling, E.J., Bigg, G.R., Ramirez, J., 2012. Paleoceanography of the Atlantic-Mediterranean exchange: Overview and first quantitative assessment of climatic forcing: Reviews of Geophysics, 50, RG2003.

Roque, C., Duarte, H., Terrinha, P., Valadares, V., Noiva, J., Cahão, M., Ferreira, J., Legoínha, P., Zitellini, N., 2012. Pliocene and Quaternary depositional model of the Algarve margin contourite drifts (Gulf of Cadiz, SW Iberia): seismic architecture, tectonic control and paleoceanographic insights. Marine Geology, 303-306, 42-62.

Roque, C., Hernández-Molina, F.J., Ercilla, G., Casas, D., Quartau, R., Llave, E., Alonso, B., Ferran, M., Mena, A., Francés, G., MOWER Cruise Party, 2015. Slope failure and mass movements in the Sines Contourite Drift (West Portuguese Margin): preliminary results. En: V. Díaz del Río, P. Bárcenas, L.M. Fernández-Salas, N. López-González, D. Palomino, J.L. Rueda, O. Sánchez-Guillamón, J.T. Vázquez (Eds.): Volumen de Comunicaciones presentadas en el VIII Simposio sobre el Margen Ibérico Atlántico, MIA15. Ediciones Sia Graf, Málaga, Spain, 579-582.

Salat, J., Cruzado, A., 1981. Masses d'eau dans la Méditerranée Occidentale. Mer Catalane et eaux adjacentes. Rapports et Proces-verbaux des Réunions. Com. Int. Explor. Sci. Mer Mediterranée, CIESM., 27, 6, 201-209.

Sánchez Goñi, M.F., Llave, E., Oliveira, D., Naughton, F., Desprat, S., Ducassou, E., Hodell, D.A., Hernández-Molina, F.J., 2016. Climate changes in south western Iberia and Mediterranean Outflow variations during two contrasting cycles of the last 1 Myrs: MIS 31-MIS 30 and MIS 12-MIS 11. Global and Planetary Change, 136, 18-29.

Sannino, G., Carillo, A., Artale, V., 2007. Three-layer view of transports and hydraulics in the Strait of Gibraltar: A three-dimensional model study. Journal of Geophysical Research, 112, C03010.

Saunders, P.M., 1982. Circulation in the Eastern North Atlantic. Journal of Marine Research, 40 (supl.), 641-657.

Schönfeld, J., Zahn, R., 2000. Late Glacial to Holocene history of the Mediterranean Outflow. Evidence from benthic foraminiferal assemblages and stable isotopes at the Portuguese margin. Palaeogeography, Palaeoclimatology, Palaeoecology, 159, 85111.

Serra, N., Ambar, I., Käse, R., 2005. Numerical modelling of the Mediterranean Water splitting and eddy generation. Deep-Sea Research II, 52, 383-408. 
Downloaded from http://sp.lyellcollection.org/ at Consejo Superior De Investigaciones Cientificas (CSIC) on March 6, 2020

Serra, N., Ambar, I., Boutov, D. 2010. Surface expression of Mediterranean Water dipoles and their contribution to the shelf/slope - open ocean exchange. Ocean Science, 6, 191-209.

Serrano, A., Maestro, A., Nozal, F. (Coords.), 2005. Memoria del mapa Geomorfológico de España a escala 1:1000.000: Geomorfología de la zona submarina española. Spanish Geological Survey (Instituto Geológico y Minero de España, IGME), 232 pp.

Shanmugam, G., 2006. Deep-water processes and facies models: Implications for sandstone petroleum reservoirs. Elsevier, $600 \mathrm{pp}$.

Shanmugam, G., 2008. Deep-water bottom currents and their deposits, In: Rebesco, M., Camerlenghi (Eds.), Contourites. Developments in Sedimentology, 60, 59-81.

Shanmugam, G., 2012. New perspectives on deep-water sandstones: Origin, recognition, initiation, and reservoir quality. Amsterdam, Elsevier, Handbook of petroleum exploration and production, 9, $524 \mathrm{pp}$.

Shanmugam, G., 2013a. Modern internal waves and internal tides along oceanic pycnoclines: challenges and implications for ancient marine baroclinic sands. American Association of Petroleum Geologists Bulletin, 97(5), 799-843.

Shanmugam, G., 2013b. New perspectives on deep-water sandstones: Implications. Petroleum Exploration and Development, 40(3), 316-324.

Shanmugam, G., Spalding, T.D., Rofheart, D.H., 1993. Processes sedimentology and reservoir quality of deep-marine bottomcurrent reworked sands (sandy contourites): an example from the Gulf of Mexico. American Association of Petrolium Geology Bulletin, 77(7), 1241- 1259.

Sierro, F.J., Flores, J.A., Zamarreño, I., Vazquez, A., Utruilla, R., Frances, G., Hilgen, F.J., Krigsman, W., 1999. Messinian climatic oscilations, astronomic cyclicity and reef growth in the western Mediterranean. Marine Geology, 153, 137-146.

Slater, D.R., 2003. The transport of Mediterranean water in the north Atlantic Ocean. PhD Thesis, Univ. of Southampton., 155 pp.

Soares, D.M., Alves, T.M., Terrinha P., 2014. Contourite drifts on distal margins as indicators of established lithospheric breakup. Earth and Planetary Science Letters, 401, 116131.

Stanley, D.J., Kelling, G., Vera, J.A., Slieng, H., 1975. Sands in the Alborán Sea: A model of input in a deep marine basin. Earth Science, 15, 51 pp.

Stoker, M.S., Akhurst, M.C., Howe, J.A., Stow, D.A.V., 1998. Sediment drifts and contourites on the continental margin off northwest Britain. Sedimentary Geology, 115, 33-51.

Stow, D.A.V., Holbrook, J.A., 1984. North Atlantic contourites: an overview. In: Stow, D.A.V., Piper, D.J.W. (Eds.), Fine-Grained Sediments: Deep-Water Processes and Facies, Geological Society of London Special Publication, 15, 245-256. 
Downloaded from http://sp.lyellcollection.org/ at Consejo Superior De Investigaciones Cientificas (CSIC) on March 6, 2020

Stow, D.AV., Mayall, M., 2000. Deep-water sedimentary systems: New models for the 21st century. Marine and Petroleum Geology, 17, 125-135.

Stow, D.A.V.. Faugères, J.-C., 2008. Contourite facies and the facies model. In: M. Rebesco and A. Camerlenghi (Eds.), Contourites. Developments in Sedimentology 60, Elsevier, 223-256.

Stow, D.A.V., Faugères, J.-C., Gonthier, E., 1986. Facies distribution and textural variation in Faro Drift contourites: velocity fluctuation and drift growth. Marine Geology, 72(1-2), 71-100.

Stow, D.A.V., Pudsey, C.J., Howe, J.A., Faugères, J.C., Viana, A. (Eds.), 2002a. Deep-water contourite systems: Modern drifts and ancient series, seismic and sedimentary characteristics. Geological Society of London Memoir, 22, 466 pp.

Stow, D.A.V., Faugères, J.C., Howe, J.A., Pudsey, C.J., Viana, A., 2002b. Bottom currents, contourites and deep-sea sediment drifts: current state-of-the-art. Geological Society of London Memoir, 22, 7-20.

Stow, D.A.V., Faugères, J.C., Gonthier, E., Llave, E., Hernández-Molina, F.J., Somoza, L., Díaz del Río, V., 2002c. Faro-Albufeira drift complex, northern Gulf of Cadiz. Geological Society of London Memoir, 22, 37-154.

Stow, D.A.V., Hernández-Molina, F.J., Hodell, D., Alvarez Zarikian, C.A., 2011a. Mediterranean outflow: environmental significance of the Mediterranean outflow water and its global implications. IODP Scientist Prospectus doi:10.2204/iodp.sp.339.

Stow, D., Brackenridge, R., Hernández-Molina, F.J., 2011b. Contourite sheet sands: new deepwater exploration target [presented at the AAPG 2011 Annual Convention and Exhibition, Houston, Texas, 10-13 April, 2011.

Stow, D.A.V., Hernández-Molina, F.J., Llave, E., García, M., Díaz del Rio, V., Somoza, L., Bruno, M., 2013a. The Cadiz Contourite Channel: Sandy Contourites, Bedforms and Dynamic Current Interaction. Marine Geology, 343, 99-114.

Stow, D.A.V., Hernández-Molina, F.J., Alvarez Zarikian, C.A. and the Expedition 339 Scientists, 2013b. Proceedings IODP, 339, Tokyo (Integrated Ocean Drilling Program Management International, Inc.). doi:10.2204/iodp.proc.339.

Thorpe, S.A., 1975. Variability of the Mediterranean in the Gulf of Cadiz. Deep Sea Research, 23, 711-727.

Toucanne, S., Mulder, T., Schönfeld, J., Hanquiez, V., Gonthier, E., Duprat, J., Cremer, M., Zaragosi, S., 2007. Contourites of the Gulf of Cadiz: A high-resolution record of the paleocirculation of the Mediterranean outflow water during the last 50,000 years. Palaeogeography, Palaeoclimatology, Palaeoecology, 246, 354-366.

Valencia, V., Franco, J., Borja, A., Fontan, A., 2004. Hydrography of the southeastern Bay of Biscay. In: Borja A. and Collins, M.B. (Eds.). Oceanography and Marine Environment of the Basque Country. Elsevier Oceanography Series, Amsterdam, 159-193. 
Downloaded from http://sp.lyellcollection.org/ at Consejo Superior De Investigaciones Cientificas (CSIC) on March 6, 2020

Van Aken, H.M., 2000. The hydrography of the mid-latitude Northeast Atlantic Ocean II: The intermediate water masses. Deep Sea Research I, 47, 789-824.

Van Aken, H.M. 2002. Surface currents in the Bay of Biscay as observed with drifters between 1995 and 1999. Deep Sea Research I, 49, 1071-1086.

Van Rooij, D., Iglesias, J., Hernández-Molina, F.J., Ercilla, G., Gomez-Ballesteros, M., Casas, D., Llave, E., De Hauwere, A., Garcia Gil, S., Acosta, J., Henriet, J.-P., 2010. The Le Danois Contourite Depositional System: Interactions between the Mediterranean Outflow Water and the upper Cantabrian slope (North Iberian margin). Marine Geology, 274, 1-20.

Vandorpe, T., Van Rooij, D., Stow, D.A.V., Henriet, J.-P., 2011. Pliocene to recent shallowwater contourite deposits on the shelf and shelf edge off south-western Mallorca, Spain. Geo-Marine Letters, 31, 391-403.

Vangriesheim, A., Khripounoff, A., 1990. Near-bottom particle concentration and flux: temporal variations observed with sediment traps and nephelometer on the Meriadzek Terrace, Bay of Biscay. Progress in Oceanography, 24, 103-116.

Vanney, J.-R., Mougenot, D., 1981. La plate-forme continentale du Portugal et les provinces adjacentes: analyse geomorphologique. Memorias dos Servicos Geologicos de Portugal, 28.

Varela, R.A., Roson, G., Herrera, J.L., Torres-Lopez, S. and Fernandez-Romero, A., 2005. A general view of the hydrographic and dynamical patterns of the Rias Baixas adjacent sea area. Journal of Marine Systems, 54, 97-113.

Vargas Yañez, M., Plaza, F., García-Lafuente, J., Sarhan, T., Vargas, J.M., Vélez Belchi, P., 2002. About the seasonal variability of the Alboran Sea circulation. Journal of Marine Systems, 35, 229248.

Velasco, J.P.B., Baraza, J., Canals, M. and Balón, J., 1996. La depresión periférica y el lomo contourítico de Menorca: evidencias de la actividad de corrientes de fondo al $\mathrm{N}$ del talud Balear. Geogaceta, 20(2), 359-362.

Vélez-Belchí, P.J., Vargas-Yáñez, M., Tintoré J., 2005. Observation of a western Alborán gyre migration event. Progress in Oceanography, 66(2-4), 190-210.

Viana, A., 2008. Economic Relevance of Contourites. In: Rebesco, M. and Camerlenghi, A, (Eds.), Contourites. Developments in Sedimentology, 60. Elsevier, 493-510.

Viana, A., Rebesco, M. (Eds.), 2007. Economic and Palaeoceanopraphic Significance of Contourite Deposits. Geological Society, London, Special Publications, 276, 350 pp.

Viana, A.R., Faugères, J.C., Stow, D.A.V., 1998. Bottom current-controlled sand deposits a review of modern shallow - to deep-water environments. Sedimentary Geology, 115, 53-80.

Viana, A.R., Hercos, C.M., Almeida Jr.,W., Magalhães, J.L.C., Andrade, S.B., 2002. Evidence of Bottom Current Influence on the Neogene to Quaternary Sedimentation Along the Northern Campos Slope, SW Atlantic Margin. In: Stow, D.A.V., Pudsey, C.J., 
Downloaded from http://sp.lyellcollection.org/ at Consejo Superior De Investigaciones Cientificas (CSIC) on March 6, 2020

Howe, J.A., Faugères, J.C., Viana, A.R. (Eds.), Deep-Water Contourite Systems: Modern Drifts and Ancient Series, Seismic and Sedimentary Characteristics. Geological Society, London, Memoirs 22, 249-259.

Viana, A.R., Almeida, W., Jr., Nunes, M.C.V., Bulhões, E.M., 2007. The economic importance of contourites. Geological Society of London Special Publication, 276(1), 123.

Viúdez, A., Pinot, J.M., Haney, R.L., 1998. On the upper layer circulation of the Alboran Sea. Journal of Geophysical Research, 103, 21 653-21 666.

Voelker, A., Lebreiro, S., Schönfeld, J., Cacho, I., Exlenkenser, H., Abrantes, F., 2006. Mediterranean outflow strengthenings during Northern Hemisphere Coolings: a salt sources for the glacial Atlantic?. Earth and Planetary Science Letters, 245, 39-55.

Voelker, A.H.L., Salgueiro, E., Rodrigues, T., Jimenez-Espejo, F.J., Bahr, A., Alberto, A., Loureiro, I., Padilha, M., Rebotim, A., Röhl, U., 2015. Sediment, isotopic and geochemical record during Marine Isotope Stages 29 to 34 of IODP Site 339-U1387. Global and Planetary Change, 133, 223-237.

Whitmarsh, R.B., Beslier, M.-O., Wallace, P.J., 1998. Proceedings of the Ocean Drilling Program, Initial Reports, 173. Site 1067, 107-161.

Wilson, R.C.L., Sawyer, D.S., Whitmarsh, R.B., Zerong, J., Carbonell, J., 1996. Seismic stratigraphy and tectonic history of the Iberia Abyssal Plain. In: Whitmarsh, R.B., Sawyer, D.S., Klaus, A., Masson, D.G. (Eds.), Proceedings. ODP, Scientific Results, 149. Ocean Drilling Program, College Station, TX, 617-633.

Wilson, R.C.L., Manatschal, G., Wise, S., 2001. Rifting along non-volcanic passive margins: stratigraphic and seismic evidence from the Mesozoic successions of the Alps and western Iberia. In: WILSON, R. C.L., Whitmarsh, R. B., Taylor, B. \& Froitzheim, N. (Eds.) Non-Volcanic Rifting of Continental Margins: A Comparison of Evidence from Land and Sea. Geological Society, London, Special Publications, 187, 429-452.

World Ocean Atlas 2012. National Oceanographic Data Center. http://www.nodc.noaa.gov/

Zenk, W., 1975. On the Mediterranean outflow west of Gibraltar. Meteor-

Forschungsergebnisse, 16, 23-34.

Zitellini, N., Gràcia, E., Matias L., Terrinha, P., Abreu, M.A., DeAlteriis, G., Henriet, J.P., Dañobeitia, J.J., Masson, D.G., Mulder, T., Ramella, R., Somoza, L., Diez, S., 2009. The Quest for the Africa-Eurasia plate boundary west of the Strait of Gibraltar. Earth and Planetary Science Letters, 280 (1-4), 13-50.

\section{FIGURE CAPTIONS}

Figure 1. Surficial, intermediate and deep-water circulation around the Iberian continental margin (modified from Hernández-Molina et al., 2011); digital bathymetric model obtained from Zitellini et al. (2009) and GEBCO (2003). Vertical hydrographic profiles: (A) East Iberian margin, (B) Gulf of Cadiz and (C) Galician margins (source data from the World Ocean Atlas, 2012). Locations of the study areas are also shown. 
Figure 2. (A) Digital bathymetric model of the northeast Iberian margin and location of the main water masses and seismic profiles. (B) Multichannel seismic profile showing a mounded drift example as well as erosive features.

Figure 3. (A) Multichannel and (B) Sparker seismic profile (modified from Velasco et al., 1996) showing mounded separated drifts and moats. (C) Multichannel seismic profile where sediment waves are developed on a plastered drift. (D) Multichannel seismic profile showing mounded and plastered drifts as well as erosional features around submarine highs. For location of the seismic profiles see Figure 2.

Figure 4. (A) Multichannel and (B) Sparker seismic profile (modified from Vandorpe et al., 2011) showing plastered drifts. For location of the seismic profiles see Figure 2.

Figure 5. Map of the Alboran Sea continental margin and locations of the main contourite features based (A) Digital bathymetric data and (B) Airgun and (C) Sparker seismic profiles (modified from Juan et al. 2012, 2013; and Ercilla et al. 2016) showing examples of plastered and mounded and separated drifts as well as erosive features.

Figure 6. (A) Airgun seismic profile showing an example of sheeted drift. (B) Airgun seismic profile showing an example of channel-related drift. (C) Sparker seismic profile showing a mounded separated drift and moat. (D) Airgun seismic profile showing a confined drift (modified from Juan et al., 2012, 2013; and Ercilla et al., 2016). For location of the seismic profiles see Figure 5.

Figure 7. (A) Digital bathymetric model of the Gulf of Cadiz continental margin and location of the main water masses. (B) Airgun seismic profile showing contourite drifts close to the Strait of Gibraltar. (C) and (D) Sparker seismic profiles showing mounded elongated and separated drift and its basinward prolongation as sheeted drift (modified from Llave et al., 2001).

Figure 8. (A), (B) and (C) Sparker seismic profiles showing deformed sheeted drifts as well as contourite channels around diapiric ridges. (D) Sparker seismic profile showing sand waves (modified from Llave et al., 2001; Hernández-Molina et al., 2006, 2014b; and García et al., 2009). For location of the seismic profiles see Figure 7.

Figure 9. (A) Airgun seismic profile where mounded drifts and contourite channels is described. (B-E) Sparker seismic profiles showing examples of contourite erosional features such as an abraded surface, an erosive scour, a furrow and a marginal valley (modified from Llave et al., 2001; Hernández-Molina et al., 2006, 2014b; and García et al., 2009). For location of the seismic profiles see Figure 7.

Figure 10. (A) Digital bathymetric model of the Western Iberian continental margin and continental rise, and location of the main water masses and seismic profiles. (B-C) Airgun and Sparker seismic profiles showing examples of mounded separated drifts and moats, and (D) sediment waves (modified from Alves et al., 2003, 2006; Pereira and Alves, 2011, and Roque et al., 2012). (E) TOPAS seismic profile where it is shown an example of plastered drift (modified from Llave et al., 2013). AM: Alentejo Margin; GB: Galicia Bank; GIB: Galicia Interior Basin; TZ: Transitional Zone; OMP: Ortegal Marginal Platform; PBMP: Pardo Bazán Marginal Platform; CMP: Castro Marginal Platform. 
Downloaded from http://sp.lyellcollection.org/ at Consejo Superior De Investigaciones Cientificas (CSIC) on

Figure 11. (A-B) TOPAS seismic profiles showing examples of mounded separated drifts and moats (modified from Ercilla et al., 2011 and Llave et al., 2013). (C) Airgun seismic profile showing the distribution three contourite terraces (modified from Llave et al., 2013). (D) TOPAS seismic profile where an abrasion surface is shown on a plastered drift (modified from Ercilla et al., 2011). For location of the seismic profiles see Figure 10.

Figure 12. (A) Digital bathymetric model of the Le Danois continental margin, and location of the main contourite features based on and location of the main water masses and seismic profiles. (B and $C$ ) Airgun seismic profiles where mounded separated drifts and moats, as well as a plastered drift are shown (modified from Van Rooij et al., 2010).

Figure 13. Standard contourite sequence of facies model, linked to variation in contourcurrent velocity (from Stow and Faugères, 2008, based on the original figure from Gonthier et al., 1984).

Figure 14. Locations and depths (in $\mathrm{m}$ ) of the main types of drifts along the lberian margin: C: confined; Ch: channel related; M: mound; P: plastered; S: separated; Sh: sheeted; Sw: sediment waves. Image also shows contourite features (red), erosive features (purple) and unpublished features (orange). See Table I for more detail regarding their characteristics.

Table I. Acronyms of the main water masses present along the Iberian margin.

Table II. Acoustic facies, morphology and location of the main contourite features along the Iberian margin.

Table III. Main HARs for contourite features along the Iberian margins. 
Downloaded from http://sp.lyellcollection.org/ at Consejo Superior De Investigaciones Cientificas (CSIC) on March 6, 2020

\begin{tabular}{|l|l|}
\hline \multicolumn{2}{|l|}{ Mediterranean Sea } \\
\hline AW & Atlantic Water \\
\hline MAW & Modified Atlantic Water \\
\hline EAG & Eastern Alboran Gyres \\
\hline WAG & Western Atlantic Gyre \\
\hline LIW & Levantine Intermediate Water \\
\hline WMDW & Western Mediterranean Deep Water \\
\hline WIW & Western Intermediate Water \\
\hline TDW & Tyrrhenian Dense Water \\
\hline LMW & Light Mediterranean Waters \\
\hline DMW & Dense Mediterranean Waters \\
\hline & Gulf of Cadiz and West Iberia \\
\hline AIW & Inflow of the Atlantic Water \\
\hline PC & Portugal Current \\
\hline PCCC & Portugal Coastal Counter Current \\
\hline ENACW & Eastern North Atlantic Central Water \\
\hline AAIW & Modified Antarctic Intermediate Water \\
\hline MOW & Mediterranean Outflow Water \\
\hline MU & Mediterranean Upper Core \\
\hline ML & Mediterranean Lower Core \\
\hline NADW & North Atlantic Deep Water \\
\hline LDW & Lower Deep Water \\
\hline LADW & Labrador Deep Water \\
\hline AABW & Antarctic Bottom Water \\
\hline & Galicia and Cantabrian \\
\hline LSW & Labrador Sea Water \\
\hline
\end{tabular}


Downloaded from http://sp.lyellcollection.org/ at Consejo Superior De Investigaciones Cientificas (CSIC) on March 6, 2020

\begin{tabular}{|c|c|c|c|}
\hline $\begin{array}{l}\text { Main } \\
\text { depositional } \\
\text { features }\end{array}$ & Acoustic Facies & Shape/Dimensions & Location \\
\hline \multicolumn{4}{|c|}{ Mediterranean Sea: Barcelona CF } \\
\hline Mounded drifts & Prograding upslope & $\begin{array}{c}\text { High mound shape, } \sim 5 \mathrm{~km} \text { wide, few hundreds of } \mathrm{m} \\
\text { of relief }\end{array}$ & Middle-lower slope \\
\hline Separated drifts & Prograding upslope & $\begin{array}{c}\text { High mound shape, } \sim 6 \mathrm{~km} \text { wide, few tens of } \mathrm{m} \text { of } \\
\text { relief }\end{array}$ & Middle slope-lower slope \\
\hline Plastered drifts & $\begin{array}{l}\text { Prograding upslope- } \\
\text { downslope }\end{array}$ & $\begin{array}{l}\text { Low mound shape, ten } \mathrm{km} \text { wide, few tens of } \mathrm{m} \text { of } \\
\text { relief }\end{array}$ & Upper-Middle slope \\
\hline \multicolumn{4}{|c|}{ Mediterranean Sea: Valencia and Balearic Islands CF } \\
\hline Plastered & $\begin{array}{l}\text { Prograding upslope- } \\
\text { downslope }\end{array}$ & $\begin{array}{c}\text { Low mound shape, ten } \mathrm{km} \text { wide, few tens of } \mathrm{m} \text { of } \\
\text { relief }\end{array}$ & Middle slope \\
\hline \multicolumn{4}{|c|}{ Mediterranean Sea: Murcia CF } \\
\hline Plastered & $\begin{array}{l}\text { Prograding upslope- } \\
\text { downslope }\end{array}$ & $\begin{array}{l}\text { Low mound shape, ten } \mathrm{km} \text { wide, few tens of } \mathrm{m} \text { of } \\
\text { relief }\end{array}$ & Middle slope \\
\hline \multicolumn{4}{|c|}{ Mediterranean Sea: Alboran CDS } \\
\hline Plastered drifts & $\begin{array}{l}\text { Prograding upslope- } \\
\text { downslope }\end{array}$ & $\begin{array}{c}\text { Low to high mound shape, up to few hundreds of km } \\
\text { long }(<300 \mathrm{~km}), 5.5 \text { to } 40 \mathrm{~km} \text { wide, tens to a few } \\
\text { hundreds of } \mathrm{m} \text { of relief }\end{array}$ & $\begin{array}{l}\text { Large drifts: Spanish and Moroccan } \\
\text { slopes; Small drifts: seamounts } \\
\text { flanks, Spanish base-of-slope }\end{array}$ \\
\hline Sheeted drifts & $\begin{array}{c}\text { Aggrading } \\
\text { subaparallel } \\
\text { stratified facies }\end{array}$ & $\begin{array}{c}\text { Subtabular geometry; } \\
\text { wide }\end{array}$ & $\begin{array}{l}\text { Large drifts: Spanish base-of-slope } \\
\text { and subbasins; Small drifts: Alboran } \\
\text { Ridge, seamounts tops }\end{array}$ \\
\hline $\begin{array}{l}\text { Channel-related } \\
\text { drifts }\end{array}$ & $\begin{array}{l}\text { Aggrading and } \\
\text { prograding } \\
\text { downward }\end{array}$ & Low mound shape. $\sim 10 \mathrm{~km}$ long, $<5 \mathrm{~km}$ wide & Alboran Trough \\
\hline $\begin{array}{l}\text { Mounded } \\
\text { confined drifts }\end{array}$ & $\begin{array}{l}\text { Prograding } \\
\text { dowmward }\end{array}$ & $\begin{array}{l}\text { High mound shape; Few to tens of km long and wide, } \\
\qquad 100 \text { to } 300 \mathrm{~m} \text { of relief }\end{array}$ & Marginal shelf banks \\
\hline Separated drifts & Prograding upslope & $\begin{array}{l}\text { Low to high mound shape; }<40 \mathrm{~km} \text { long, } 20 \mathrm{~km} \\
\text { wide, few tens of } \mathrm{m} \text { of relief }\end{array}$ & $\begin{array}{l}\text { Moroccan slope and shelf-break } \\
\text { scarp; Locally at the foot of } \\
\text { seamounts and diapirs }\end{array}$ \\
\hline \multicolumn{4}{|c|}{ Atlantic: Gulf of Cadiz CDS } \\
\hline Plastered drifts & $\begin{array}{l}\text { Prograding and } \\
\text { aggrading } \\
\text { downward }\end{array}$ & 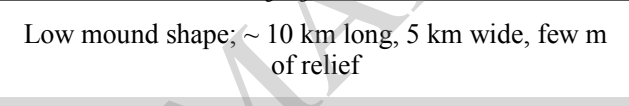 & Upper-middle slope \\
\hline Separated drifts & Prograding upslope & $\begin{array}{l}\text { High mound shape; } 90 \mathrm{~km} \text { long, } 10-20 \mathrm{~km} \text { wide, } 150- \\
\qquad 200 \mathrm{~m} \text { of } \mathrm{m} \text { of relief }\end{array}$ & Middle and Lower slope \\
\hline Sheeted drifts & $\begin{array}{c}\text { Aggrading } \\
\text { subaparallel } \\
\text { stratified facies }\end{array}$ & $\begin{array}{l}\text { Subtabular geometry; hundreds of } \mathrm{km} \text { long, tens } \mathrm{km} \\
\text { wide }\end{array}$ & Middle slope \\
\hline Mounded drift & Prograding upslope & $\begin{aligned} \text { Low mound shape; } \sim & 10 \mathrm{~km} \text { long, } \sim 10 \mathrm{~km} \text { wide, few } \\
& \mathrm{m} \text { of relief }\end{aligned}$ & Middle-Lower slope \\
\hline Separated drifts & Prograding upslope & $\begin{array}{c}\text { High mound shape; } 5 \mathrm{~km} \text { long, } 5 \mathrm{~km} \text { wide, few } \\
\text { hundreds of } \mathrm{m} \text { of relief }\end{array}$ & $\begin{array}{l}\text { Middle-Lower slope; around } \\
\text { structural high continental rise }\end{array}$ \\
\hline \multicolumn{4}{|c|}{ Atlantic: Galicia \& Ortegal CDS } \\
\hline Plastered drifts & $\begin{array}{l}\text { Prograding- } \\
\text { aggrading upslope- } \\
\text { downslope }\end{array}$ & $\begin{array}{l}\text { Low mound shape, few } \mathrm{km} \text { long, tens to few hundreds } \\
\text { of } \mathrm{m} \text { of relief }\end{array}$ & $\begin{array}{l}\text { Middle-lower slope; at the base if } \\
\text { structural highs slope-abyssal plain }\end{array}$ \\
\hline Separated drifts & Prograding upslope & $\begin{array}{l}\text { Low to high mound shape; } 522 \mathrm{~km} \text { long, } 1-10 \mathrm{~km} \\
\text { wide, few tens to few hundred of m of relief }\end{array}$ & Middle-lower slope \\
\hline \multicolumn{4}{|c|}{ Atlantic: Le Danois CDS } \\
\hline Plastered drifts & $\begin{array}{l}\text { Prograding upslope- } \\
\text { downslope }\end{array}$ & $\begin{array}{l}\text { Low mound shape, } 10-20 \mathrm{~km} \text { long, } \sim 6 \mathrm{~km} \text { wide, few } \\
\text { m of relief }\end{array}$ & $\begin{array}{l}\text { Upper southern slope of Le Danois } \\
\text { Bank }\end{array}$ \\
\hline Separated drifts & Prograding upslope & $\begin{array}{l}\text { High mound shape; } 10-45 \mathrm{~km} \text { long, } 3-10 \mathrm{~km} \text { wide, } \\
\text { few tens of m of relief }\end{array}$ & Middle slope \\
\hline
\end{tabular}


Downloaded from http://sp.lyellcollection.org/ at Consejo Superior De Investigaciones Cientificas (CSIC) on March 6, 2020

\begin{tabular}{|c|c|c|c|}
\hline Seismic section & $\begin{array}{l}\text { Seismic facies } \\
\text { characteristics }\end{array}$ & Depositional setting & Location \\
\hline 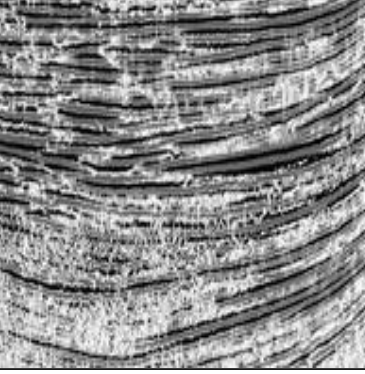 & $\begin{array}{l}\text { Transparent layers } \\
\text { intercalated with } \\
\text { high/moderate } \\
\text { amplitude reflectors }\end{array}$ & Sheeted drifts & $\begin{array}{l}\text { Proximal sector Gulf of } \\
\text { Cádiz CDS }\end{array}$ \\
\hline & \begin{tabular}{|l|} 
Smooth, parallel \\
moderate to high \\
amplitude reflectors \\
typically interbedded \\
with transparent \\
zones \\
\end{tabular} & $\begin{array}{l}\text { Plastered drifts and } \\
\text { throughout mounded, } \\
\text { confined and channel- } \\
\text { related drifts }\end{array}$ & $\begin{array}{l}\text { Around Iberia middle } \\
\text { continental slopes }\end{array}$ \\
\hline & $\begin{array}{l}\text { Short, discontinuous } \\
\text { to chaotic reflectors of } \\
\text { moderate/high } \\
\text { amplitude reflectors }\end{array}$ & 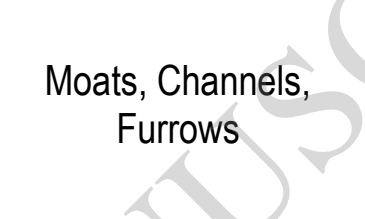 & $\begin{array}{c}\text { Around lberian } \\
\text { continental slope } \\
\text { bathymetric irregularities }\end{array}$ \\
\hline & $\begin{array}{l}\text { Sigmoid and/or } \\
\text { oblique progradational } \\
\text { reflectors with strong } \\
\text { downstream migration }\end{array}$ & Mounded drifts & $\begin{array}{l}\text { Around Iberia middle } \\
\text { continental slopes }\end{array}$ \\
\hline & Gently wavy reflectors & $\begin{array}{l}\text { Over parts of several } \\
\text { drifts }\end{array}$ & $\begin{array}{l}\text { Around Iberia middle } \\
\text { continental slopes and } \\
\text { rise }\end{array}$ \\
\hline & $\begin{array}{l}\text { Horizontal or low- } \\
\text { inclination } \\
\text { high/moderate } \\
\text { amplitude reflectors } \\
\text { truncated by HARs } \\
\text { erosional surfaces }\end{array}$ & Contourite terraces & $\begin{array}{l}\text { Alboran Sea, Gulf of } \\
\text { Cadiz, Galician margin } \\
\text { (marginal platforms) }\end{array}$ \\
\hline
\end{tabular}


Downloaded from http://sp.lyellcollection.org/ at Consejo Superior De Investigaciones Cientificas (CSIC) on March 6, 2020

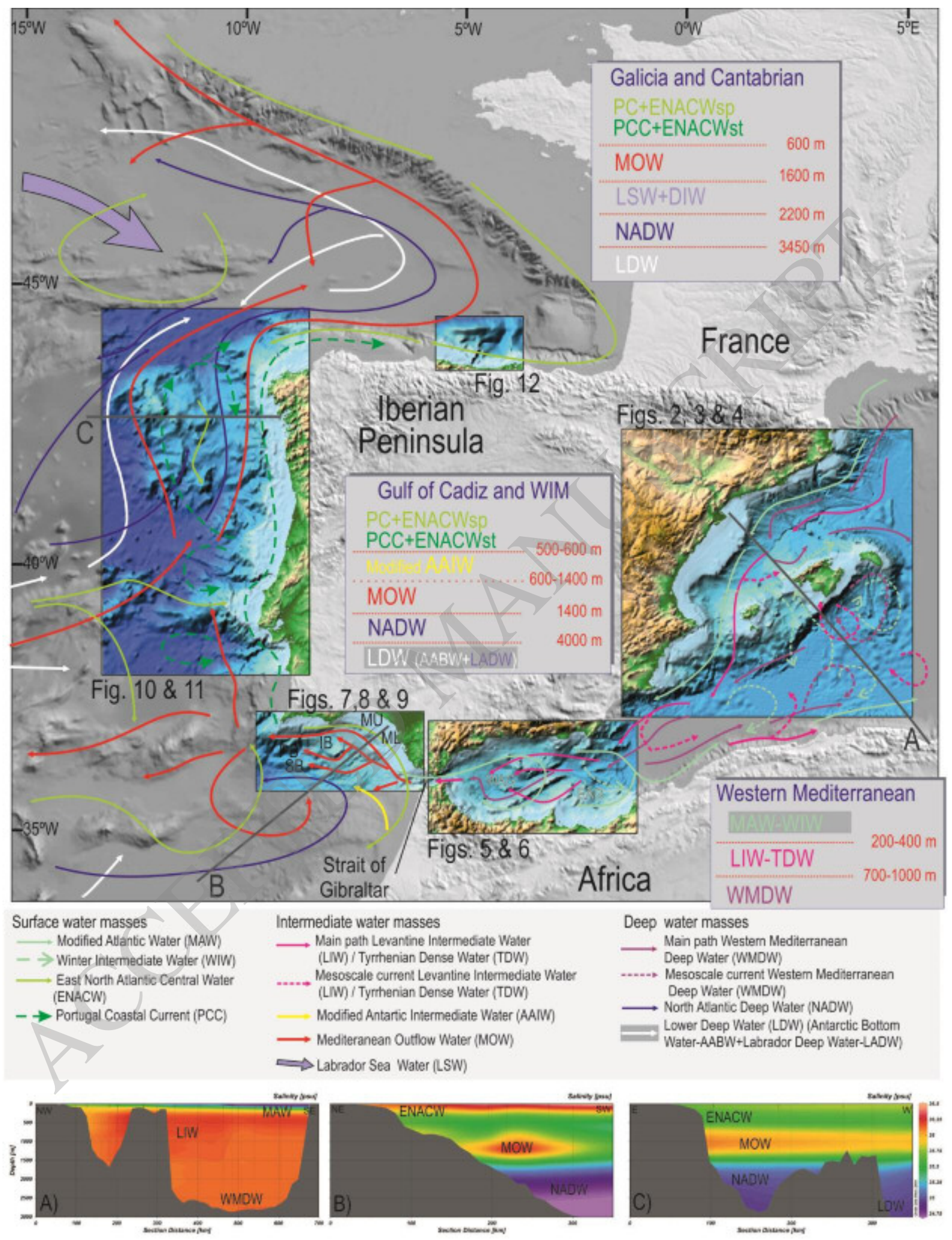

Figure 1 
Downloaded from http://sp.lyellcollection.org/ at Consejo Superior De Investigaciones Cientificas (CSIC) on March 6, 2020
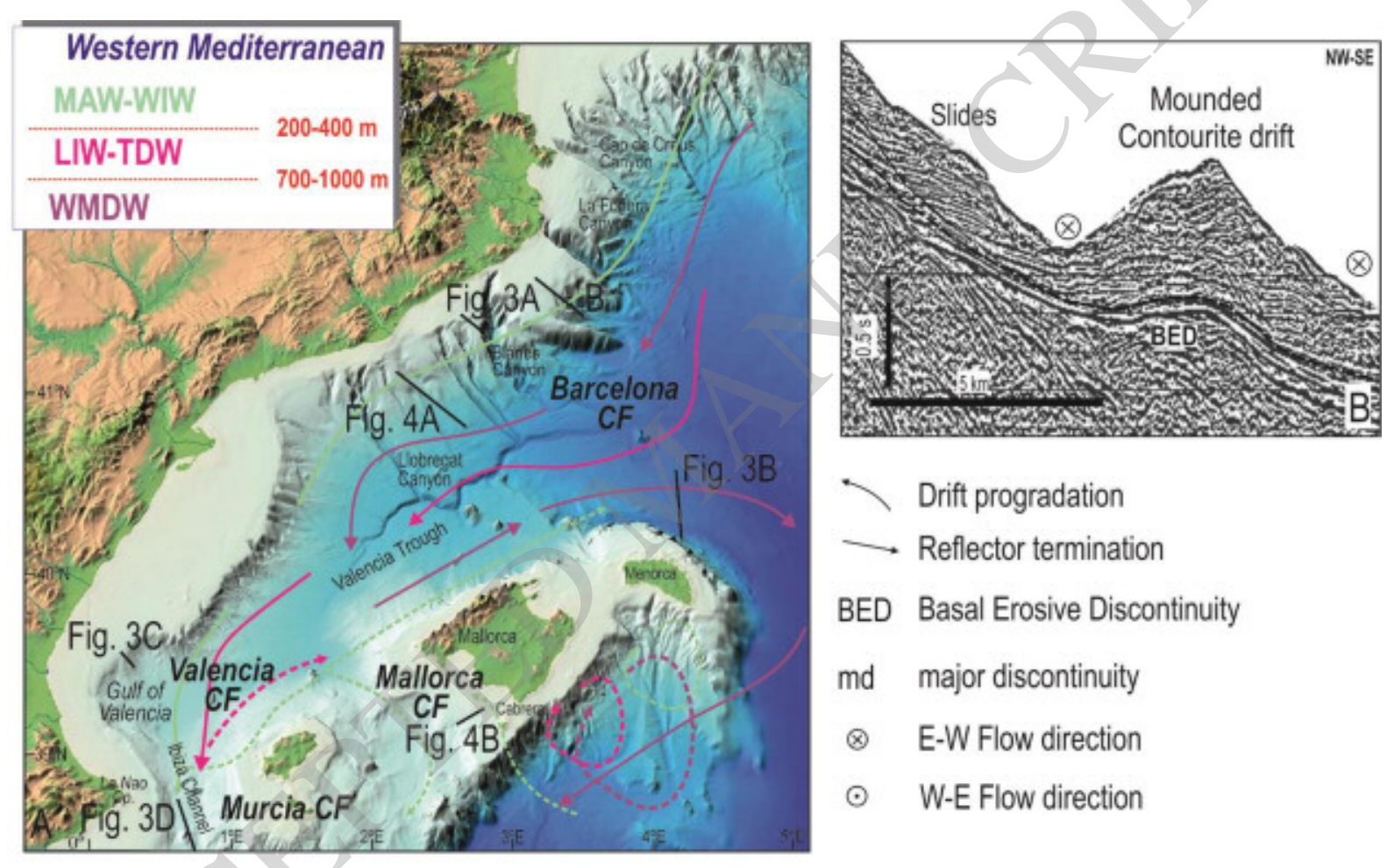

Drift progradation

Reflector termination

BED Basal Erosive Discontinuity

md major discontinuity

$\otimes \quad$ E-W Flow direction

$\odot \quad$ W-E Flow direction

\section{Figure 2}


Downloaded from http://sp.lyellcollection.org/ at Consejo Superior De Investigaciones Cientificas (CSIC) on March 6, 2020
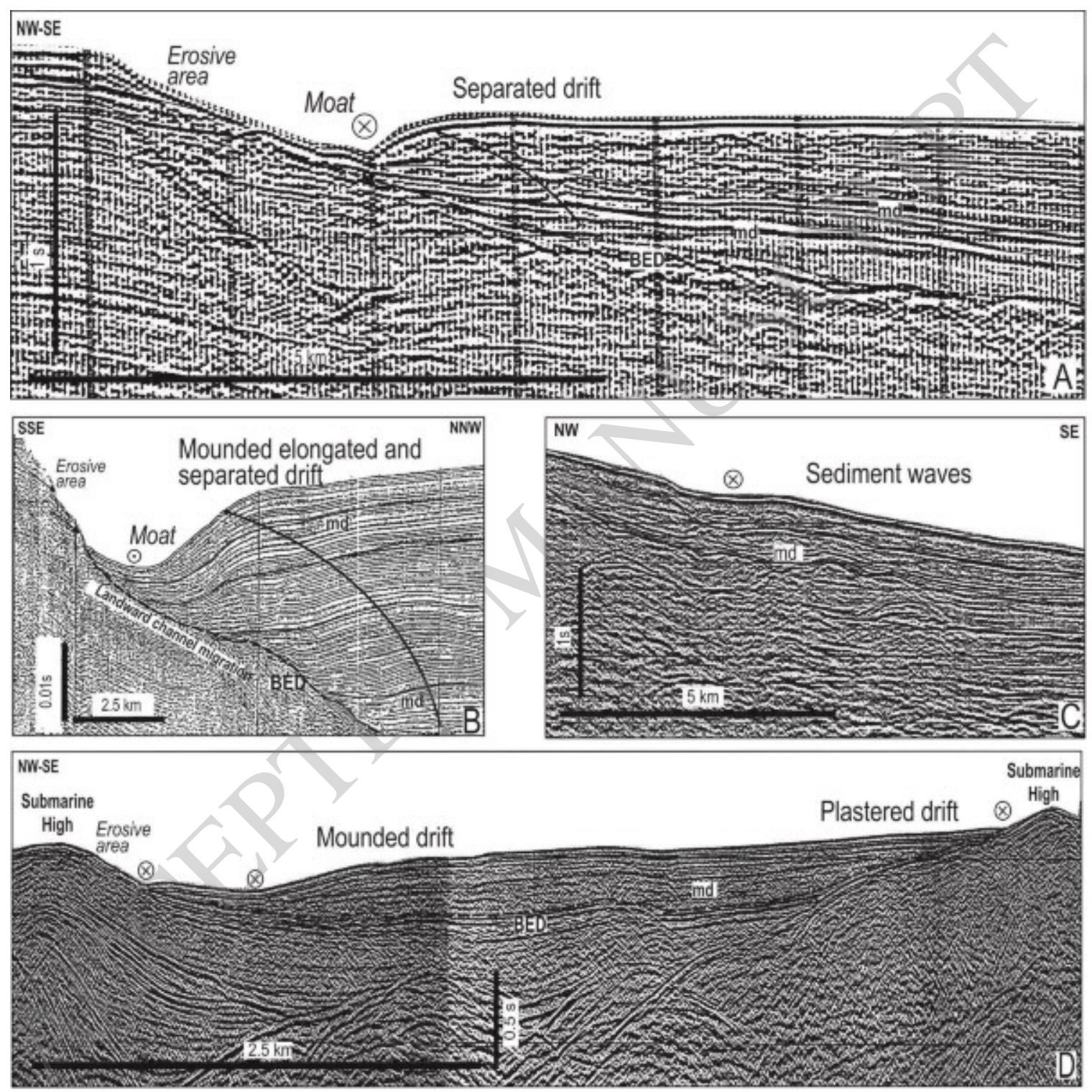

Figure 3 
Downloaded from http://sp.lyellcollection.org/ at Consejo Superior De Investigaciones Cientificas (CSIC) on March 6, 2020
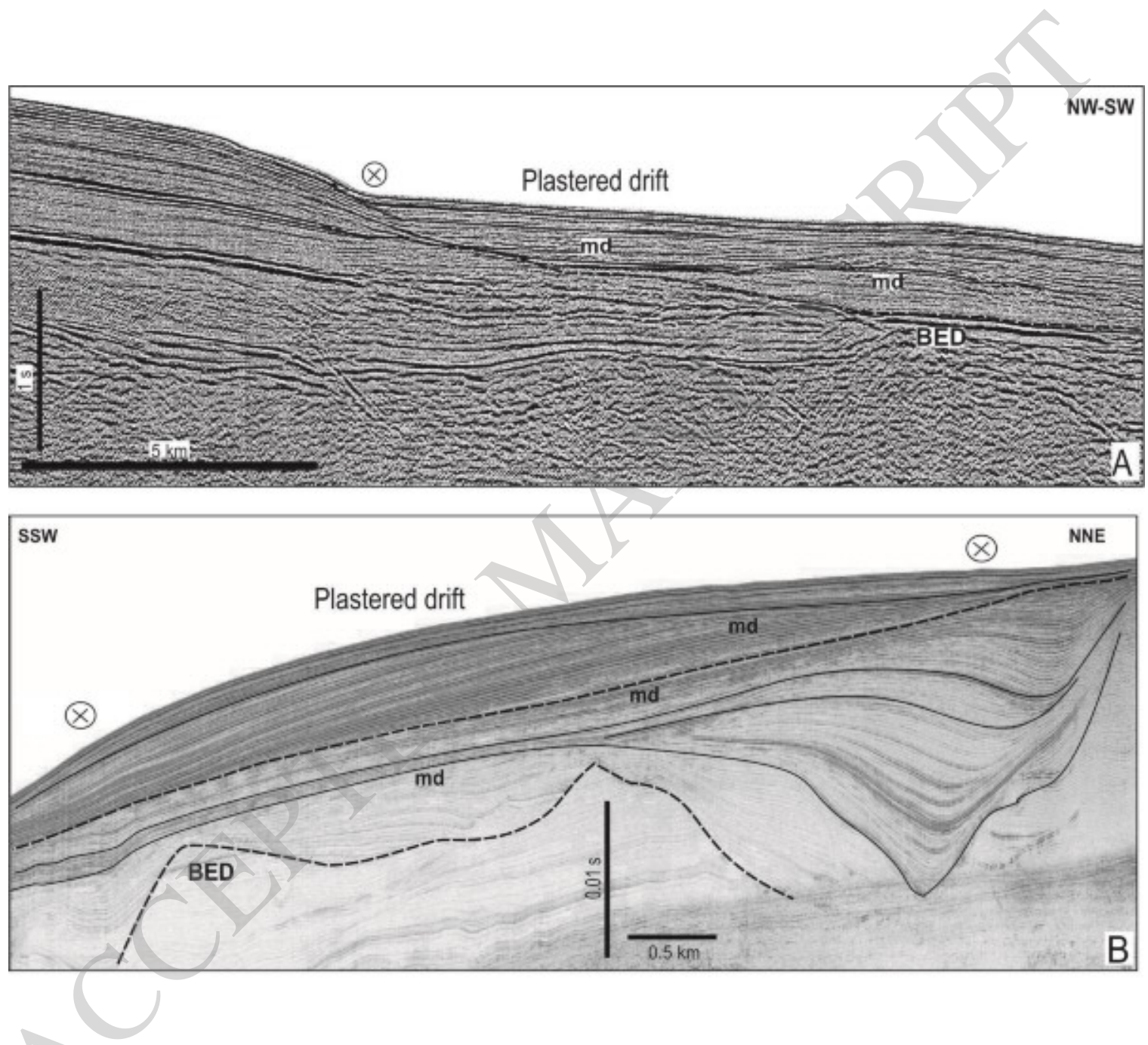

Figure 4 
Downloaded from http://sp.lyellcollection.org/ at Consejo Superior De Investigaciones Cientificas (CSIC) on March 6, 2020

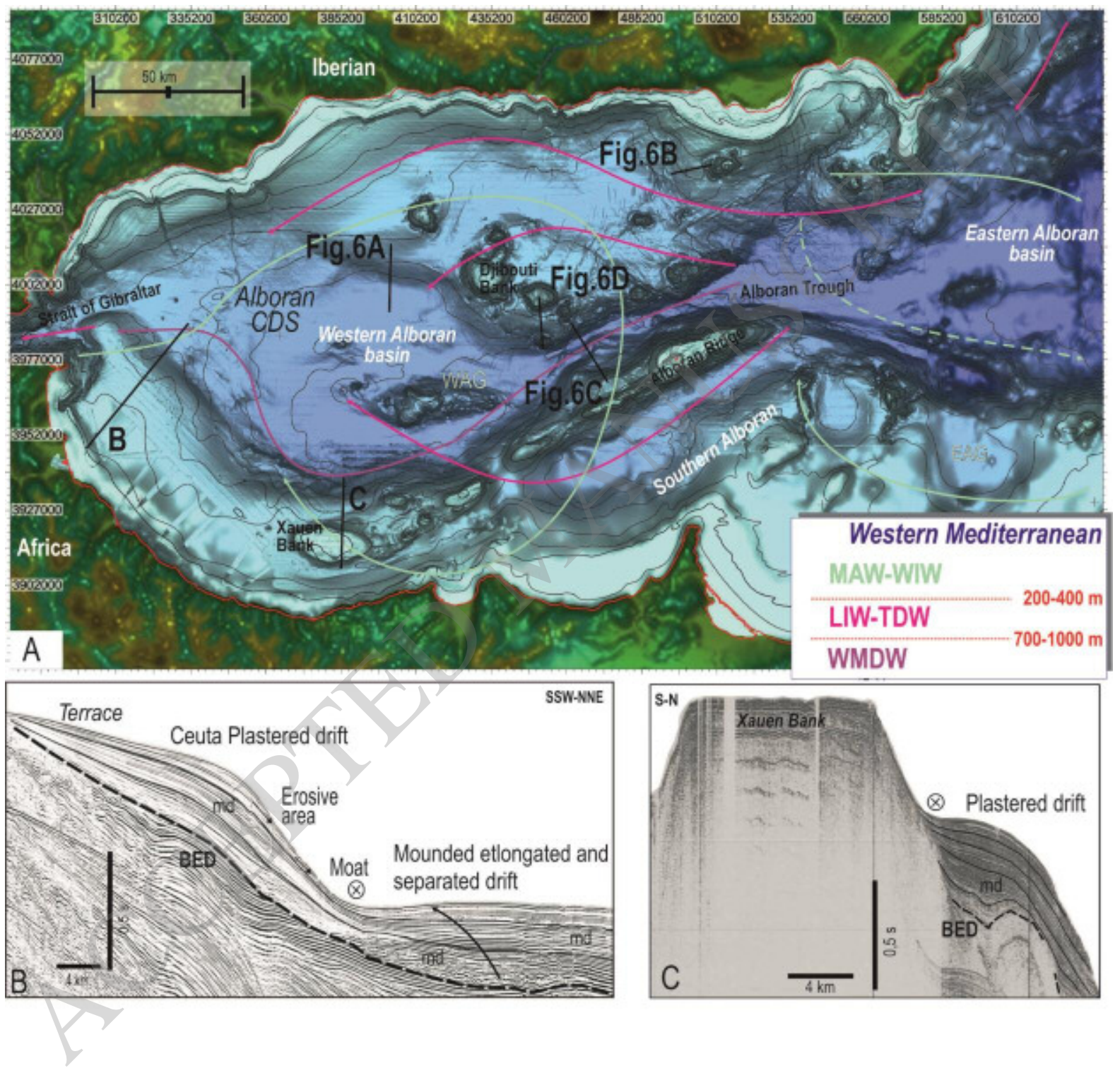

Figure 5 
Downloaded from http://sp.lyellcollection.org/ at Consejo Superior De Investigaciones Cientificas (CSIC) on March 6, 2020
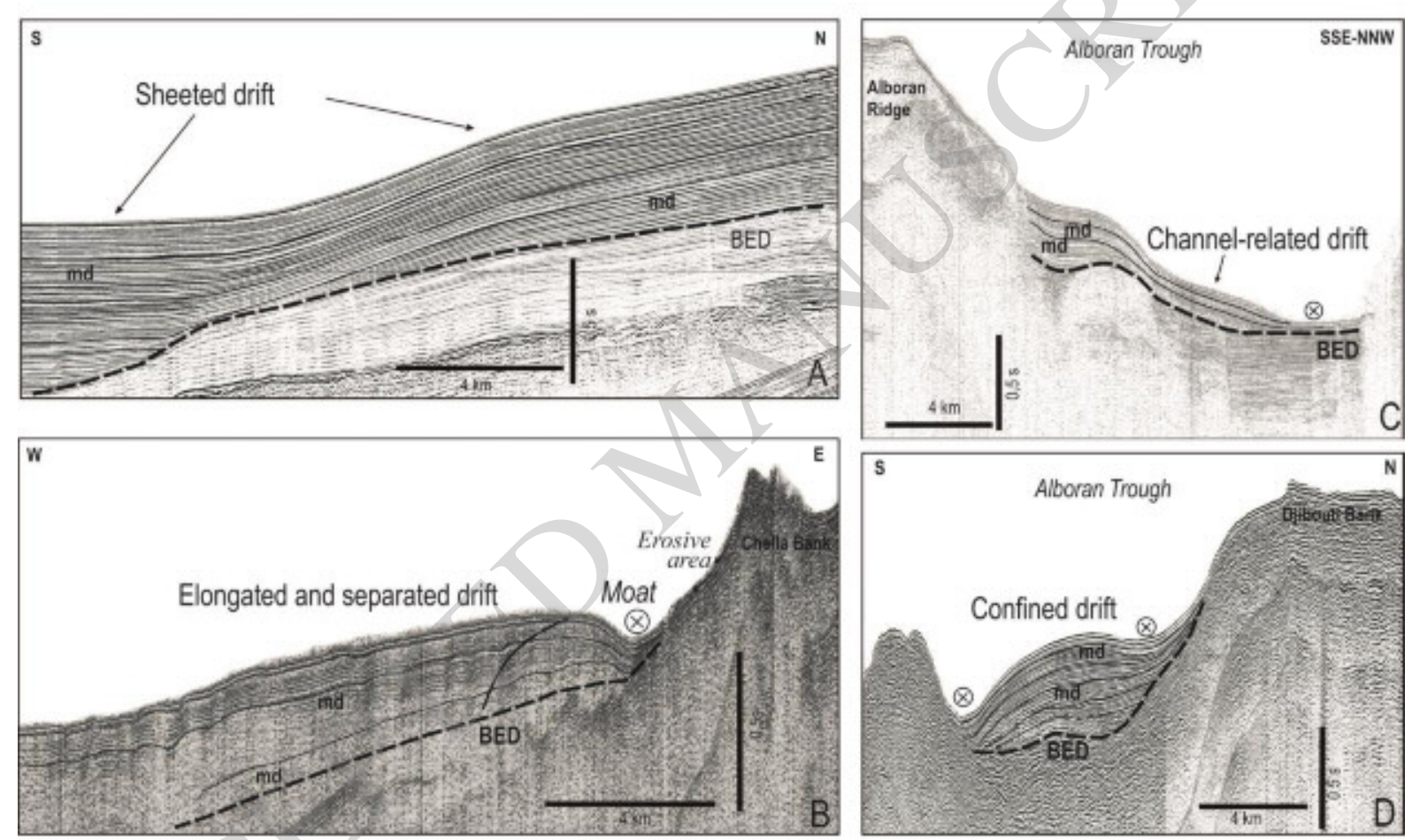

Figure 6 
Downloaded from http://sp.lyellcollection.org/ at Consejo Superior De Investigaciones Cientificas (CSIC) on March 6, 2020

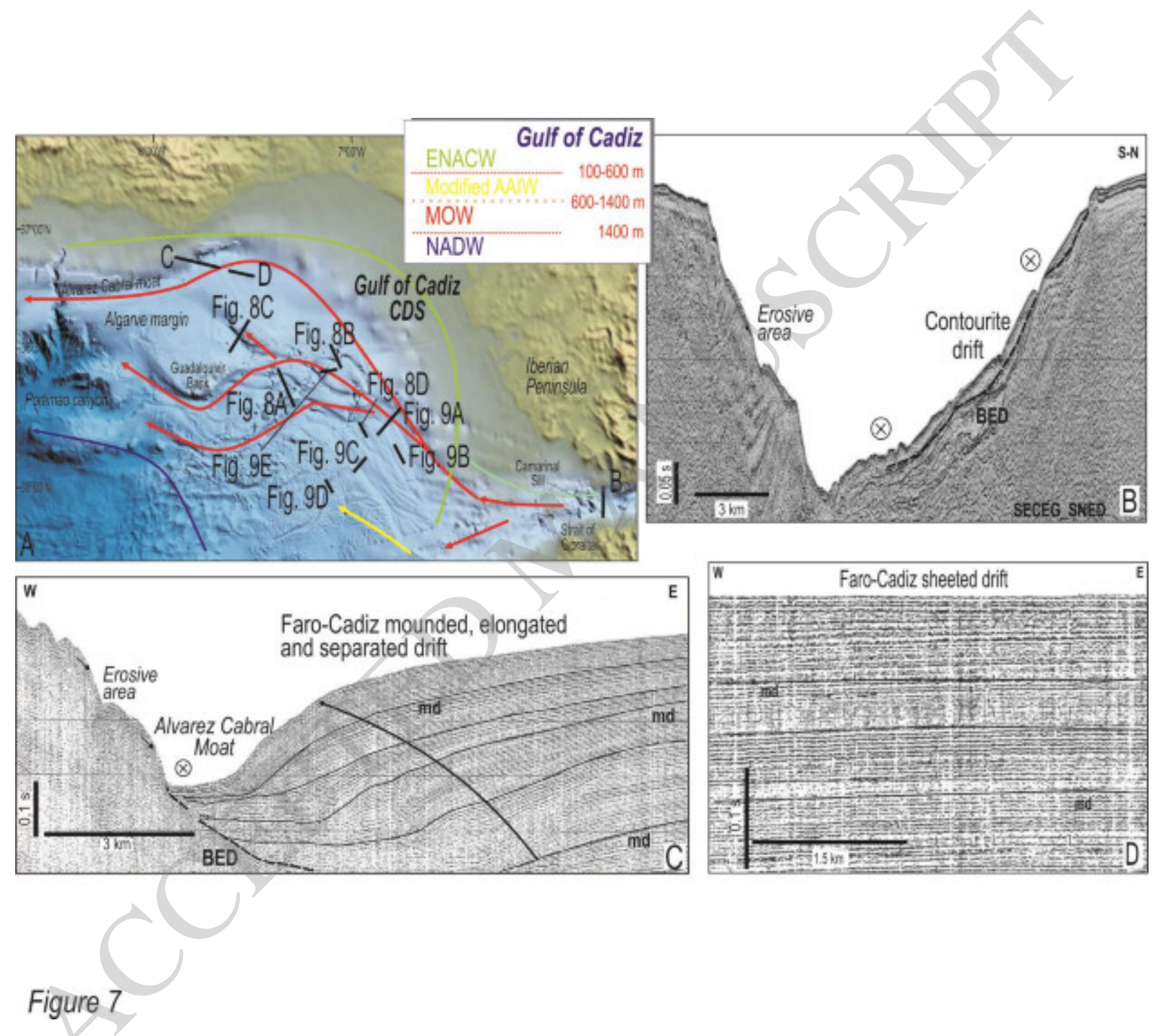


Downloaded from http://sp.lyellcollection.org/ at Consejo Superior De Investigaciones Cientificas (CSIC) on March 6, 2020

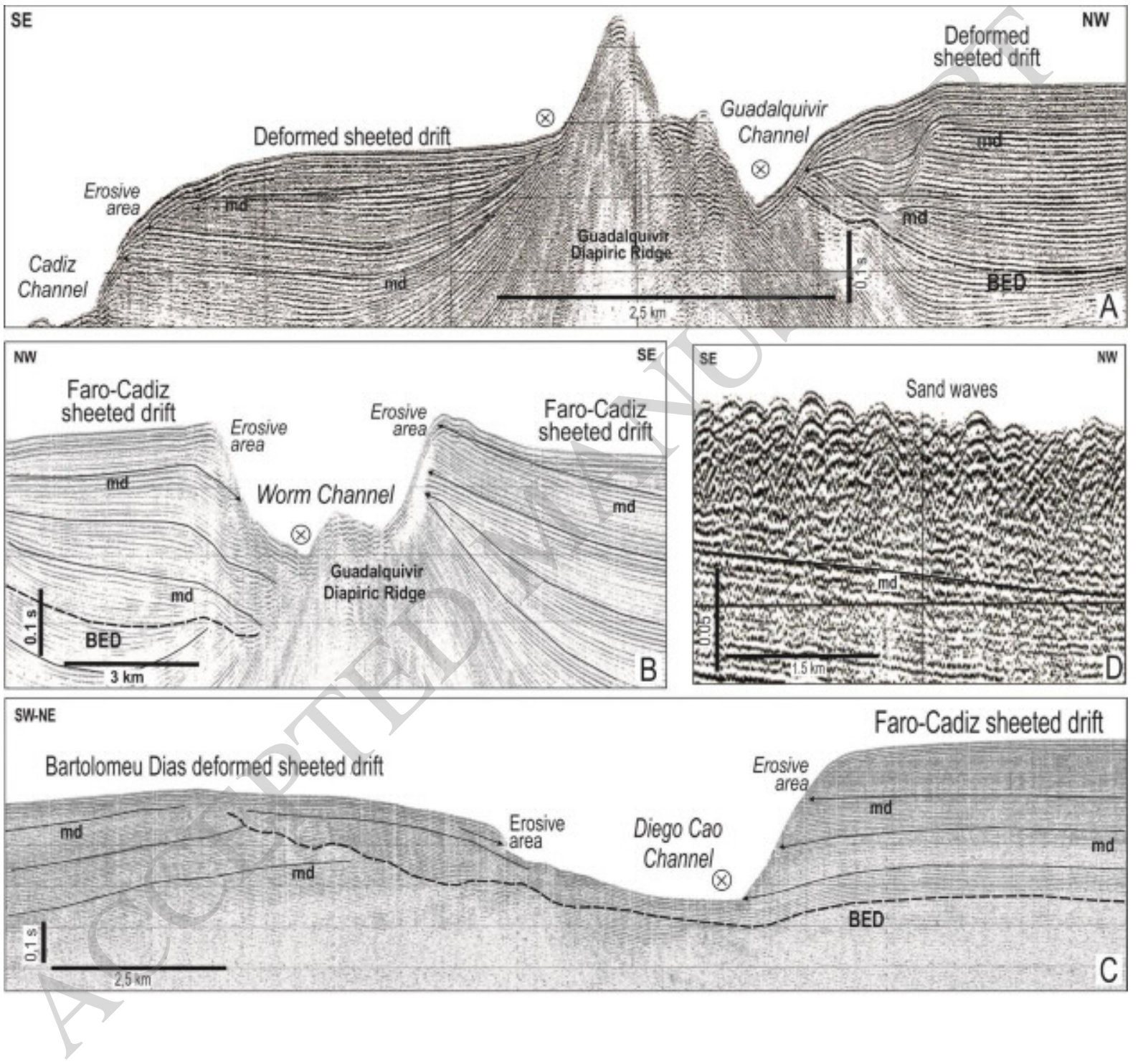

Figure 8 
Downloaded from http://sp.lyellcollection.org/ at Consejo Superior De Investigaciones Cientificas (CSIC) on March 6, 2020
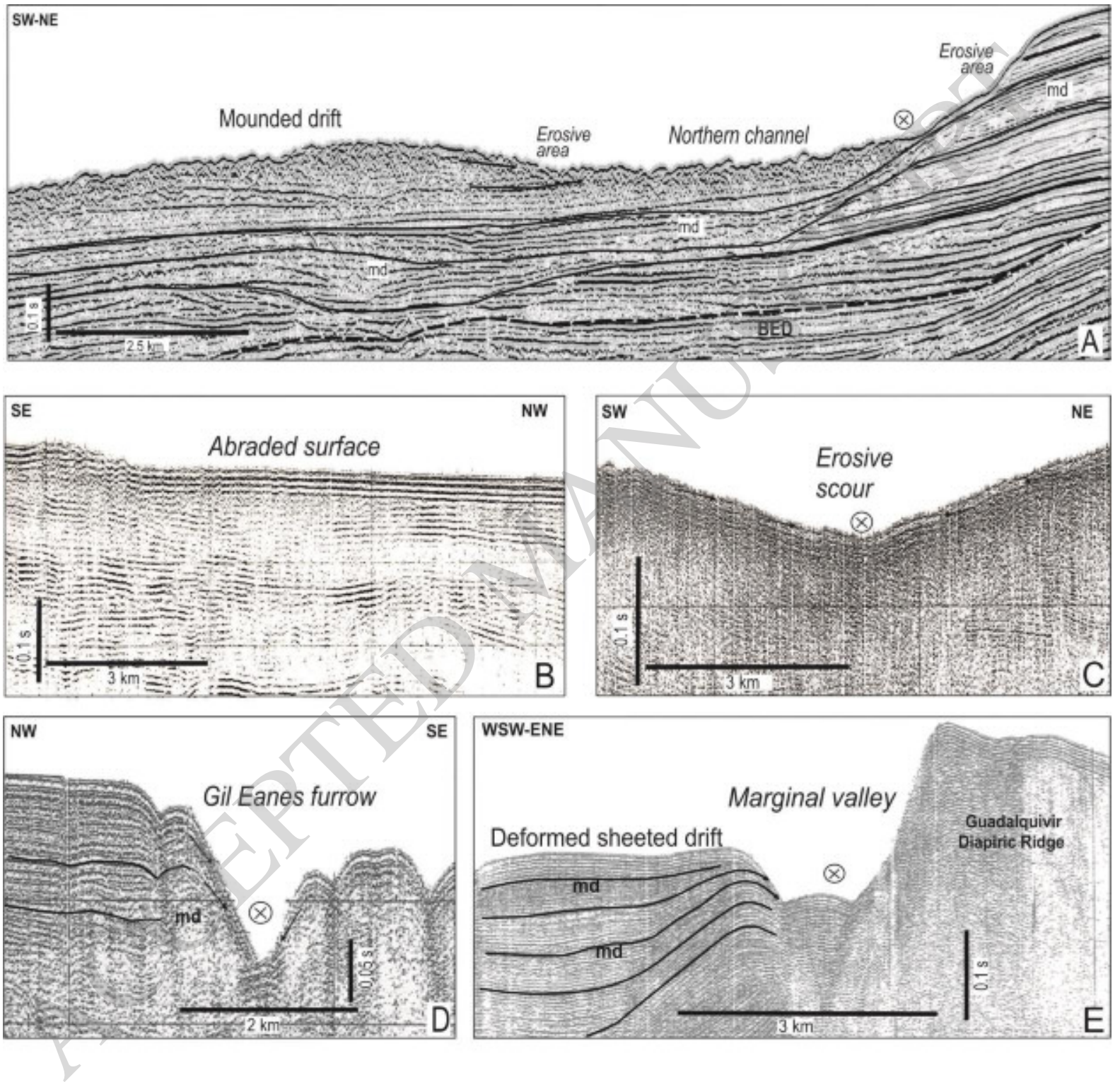

Figure 9 
Downloaded from http://sp.lyellcollection.org/ at Consejo Superior De Investigaciones Cientificas (CSIC) on March 6, 2020
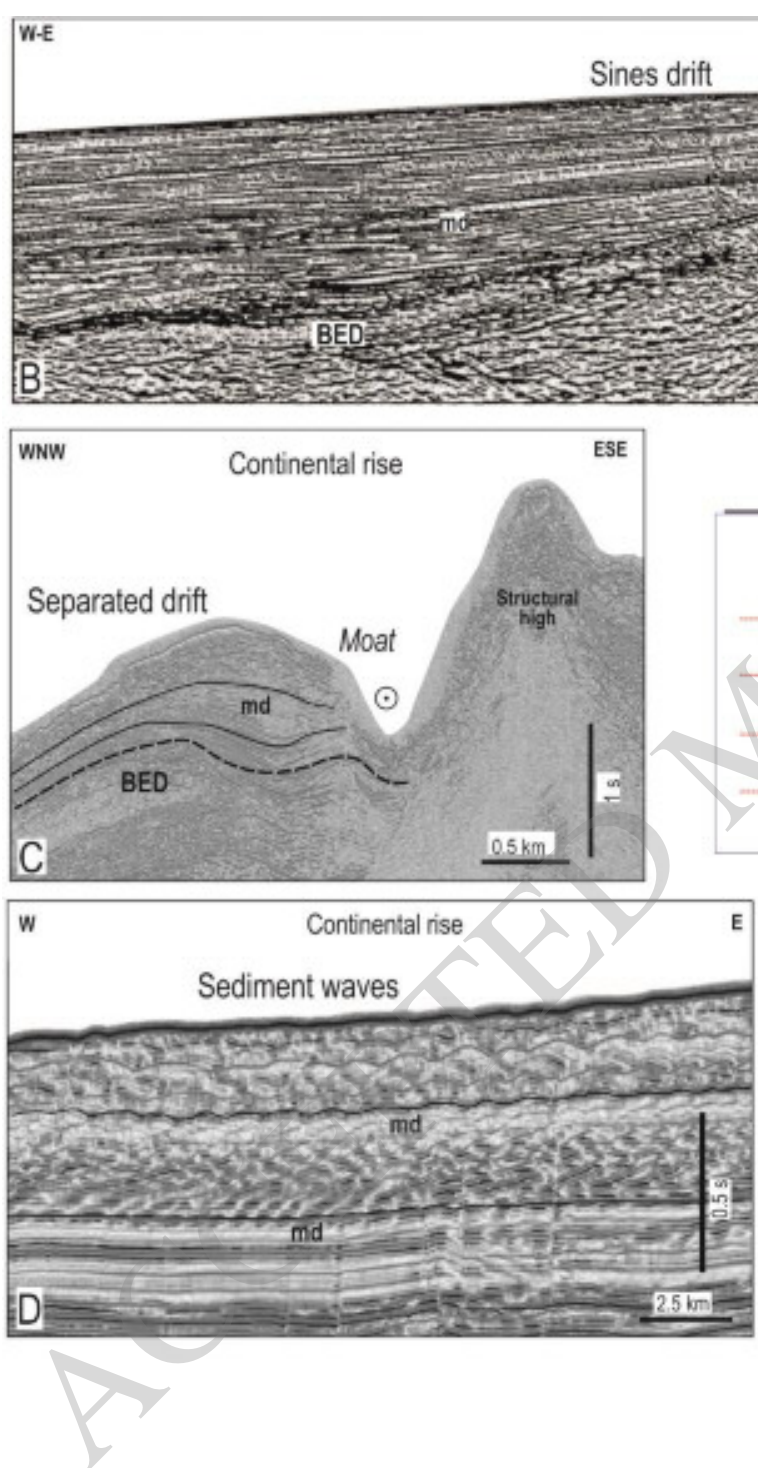

Figure 10

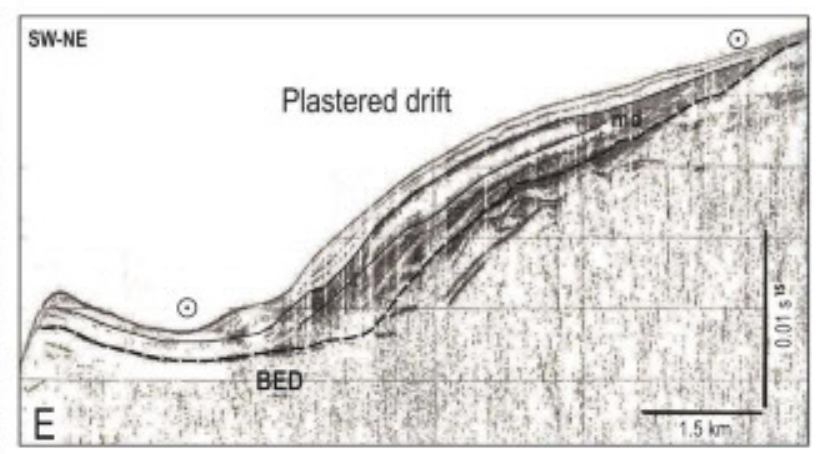


Downloaded from http://sp.lyellcollection.org/ at Consejo Superior De Investigaciones Cientificas (CSIC) on March 6, 2020
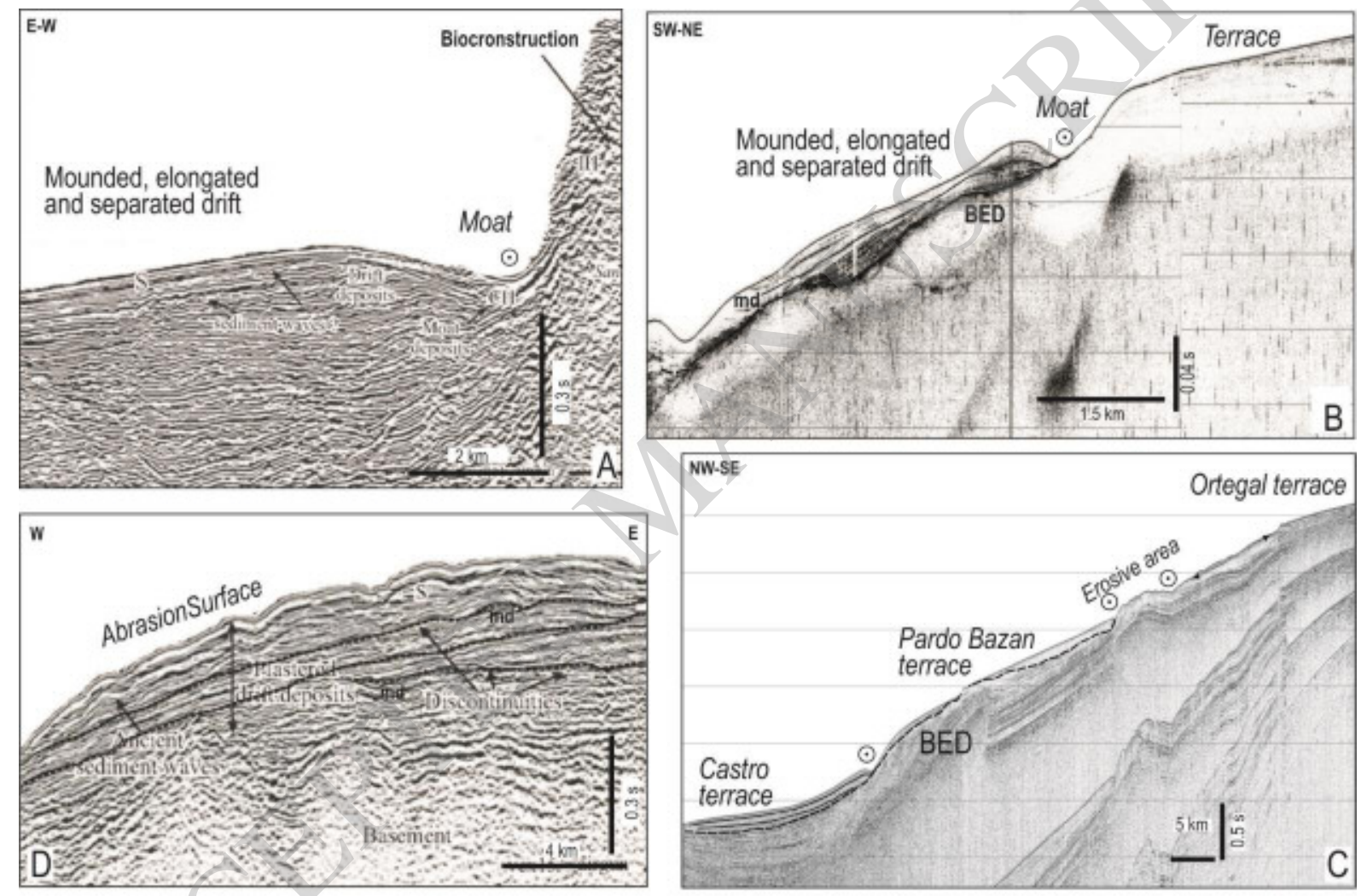

Figure 11

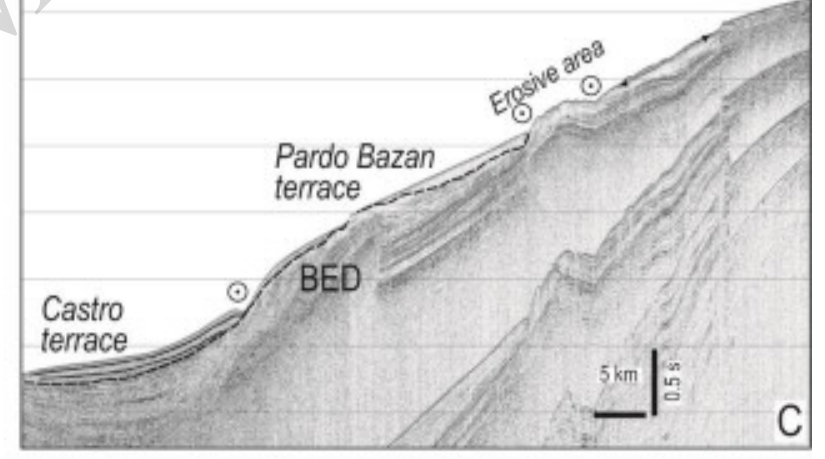


Downloaded from http://sp.lyellcollection.org/ at Consejo Superior De Investigaciones Cientificas (CSIC) on March 6, 2020

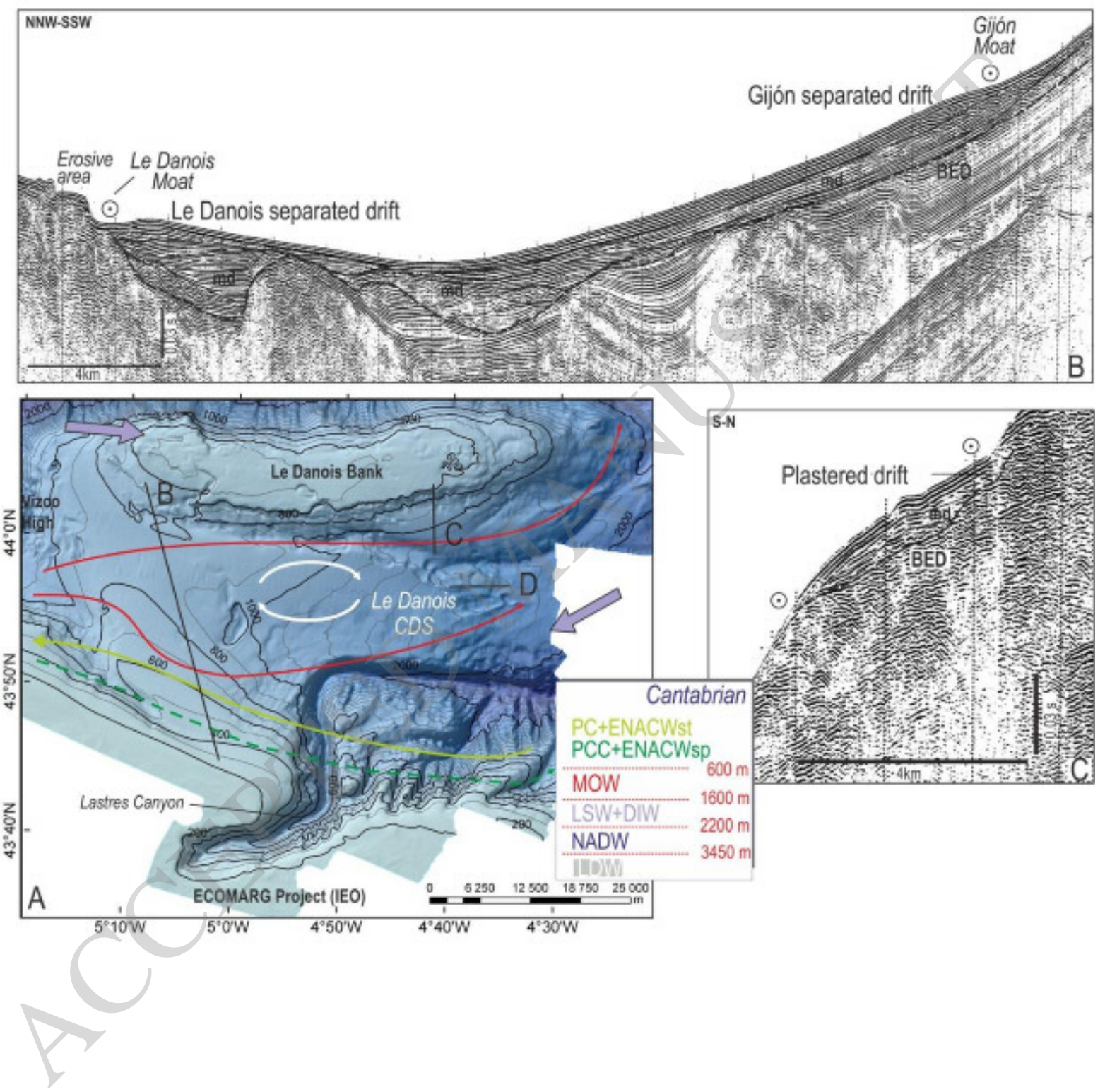

Figure 12 
Downloaded from http://sp.lyellcollection.org/ at Consejo Superior De Investigaciones Cientificas (CSIC) on March 6, 2020

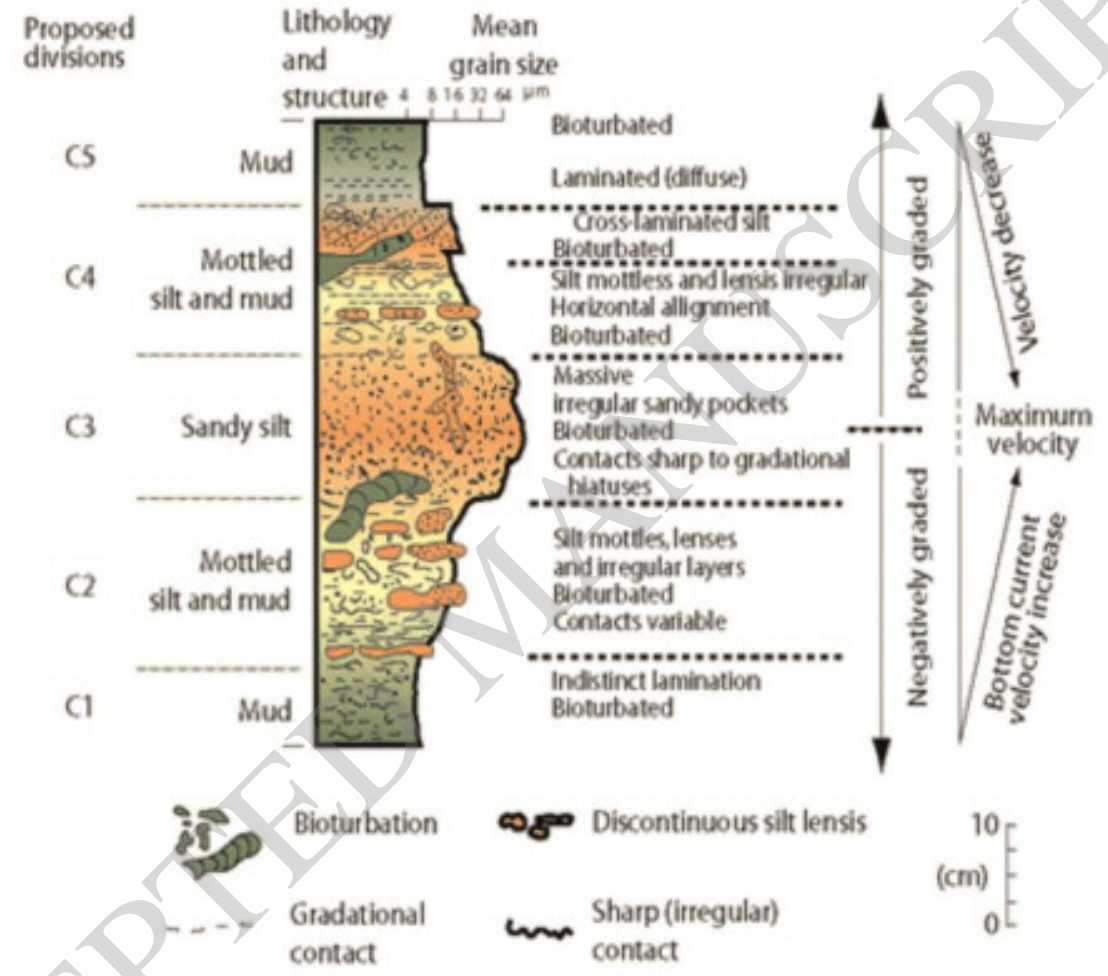

Figure 13 
Downloaded from http://sp.lyellcollection.org/ at Consejo Superior De Investigaciones Cientificas (CSIC) on March 6, 2020

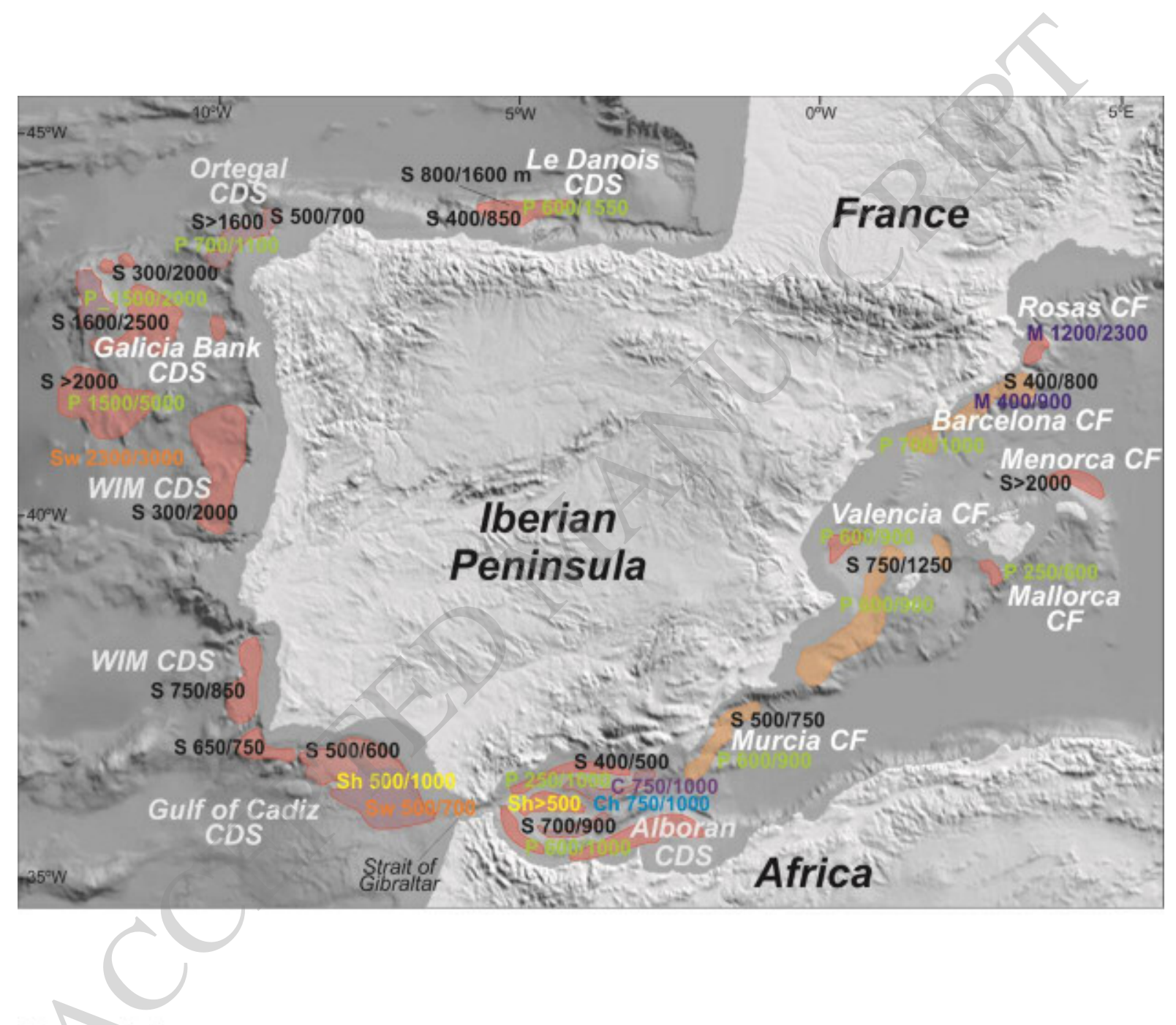

Figure 14 